\title{
The Impact of Exchange Rate Volatility on Trade: A Panel Study on Pakistan's Trading Partners
}

\author{
Abdul Jalil Khan, ${ }^{*}$ Parvez Azim, ${ }^{* *}$ and Shabib Haider Syed ${ }^{* * *}$
}

\begin{abstract}
This study investigates the impact of domestic and foreign currencyvalued exchange rate volatility on the export and import demand functions with reference to Pakistan's trading partners. We use GARCH-based exchange rate volatilities and the least-squares dummy variable technique with fixed-effects estimation to measure the volatility impact on both demand functions. The study evaluates a series of exchange rates from 1970:01 to 2009:12 to compare the longrun impact of volatility with that of the short run. The results show that, when Pakistan employed the US dollar as the vehicle currency with its trading partners, volatility discouraged both imports and exports. In contrast, both the import and export demand functions remained unaffected by volatility distortions when Pakistan traded with its developing partners using bilateral exchange rates valued in domestic currency terms. In policy terms, this implies that Pakistan should opt for direct domestic currency when trading with middle- and low-income countries.
\end{abstract}

Keywords: GARCH models, foreign exchange markets, volatility, panel data, fixed-effects model, international financial markets, foreign exchange policy, trade, Pakistan.

JEL classification: C53, F31, F44, C23, G15, O24, F1.

\section{Introduction}

Exchange rates affect the true prices of commodities traded among countries of the world; it determines the price actually paid when each trade transaction is executed. At the same time, domestic inflation also plays a vital role in determining the changing patterns in the prices of tradable commodities (which may be intensified by exchange rate instability). However, using a single currency such as the US dollar (USD) as a vehicle currency can help insulate trade from such distortions by

* PhD scholar, Government College University, Lahore, Pakistan.

** Visiting faculty member, Government College University, Lahore; Dean, Faculty of Arts and Social Sciences, GC University, Faisalabad, Pakistan.

*** Associate professor and former chairperson, Department of Economics, Forman Christian College University, Lahore, Pakistan. 
keeping the domestic currency exchange rate stable, either by setting a fixed rate or controlling it through a peg. This strategy can help lowincome developing countries address uncertainties in trade flows.

For developing countries, problems regarding trade intensify when, along with inflation, external elements emerge in the form of "shocks" or "news" and disturb the flow of international prices paid for commodities or stocks. Such elements disrupt smooth and regular exchange rate flows and are often manifested through currency crises and stock market crashes (see Hernández \& Schmidt-Hebbel, 2002. Sometimes, such distortions may also be artificially generated in the form of "speculation." Exchange rates often exhibit highly unstable and indeterminable patterns in response to these shocks, and the resulting pattern is referred to as "volatility." If such a shock lasts long and has a temporal impact that causes a wave in the flow of exchange rates, and if these waves deter or delay the movement of exchange rates back to their original state, the consequent trade patterns will disturb the stream of expected returns by raising the probability of loss for the traders concerned.

It is important to understand how frequently such shocks might occur and how long they might persist. This necessitates the formulation of effective strategies and policies to protect traders' interests and to keep their incentive to trade intact. A review of the historical research on exchange rate volatility reveals that there is no consensus on how to estimate the precise impact of volatility on international trade flows; such methods tend to split into four streams (see Table 1). Increasingly, the literature leans toward two main outcomes: (i) a significant negative impact of exchange rate volatility on trade and (ii) no or an insignificant impact on trade. However, these outcomes remain highly subjective due to the nature, size, and type of sample; the frequency of data; the nature of the volatility proxy; and the estimation techniques employed for analysis (Ozturk, 2006). Nevertheless, the more common outcome observed in the literature is that of a significantly inverse relationship between trade and exchange rate volatility (see Table 5.1).

Traders usually respond in a variety of ways when facing a "risk" element. Since trade-related risk intensifies on arrival of a news/shock element in the market, many traders may try to expand their trade to compensate for the expected loss in profit margins by revising their portfolios (the "modern [risk portfolio]" school of thought). Others may reduce their trade volume by diverting investments from high-risk ventures to low-risk ones (the "traditional" school of thought). 
As far as data frequency is concerned, many studies have employed relatively low-frequency data such as annual, biannual, or quarterly series to measure the volatility impact (see Berger, Sturm, \& de Haan, 2000; Bénassy-Quéré, Fontagné, \& Lahrèche-Révil, 2001; Bahmani-Oskooee, 2002; Crowley \& Lee, 2003; Mustafa \& Nishat, 2004; Kemal, 2005; Azid, Jamil, \& Kousar, 2005; Chit, Rizov, \& Willenbockel, 2008; Aliyu, 2008). In time-series analyses, most models are developed to estimate high-frequency data. However, if such models are applied to low-frequency data, this can give rise to skepticism about the results because the first three moments' parameters may strongly influence the results. Time-series econometricians thus caution against this use and hold that the consequent reliability of results needs at least 300 observations (Siddiqui, 2009).

High-frequency data contains values recorded on the basis of monthly, weekly, daily, or even minute-by-minute intervals. Recent studies on exchange rates have also started to employ high-frequency data (see Andersen, Bollerslev, Diebold, \& Labys, 2001; Canales-Kriljenko \& Habermeier, 2004; Qayyum \& Kemal, 2006; Beine et al., 2006). We consider monthly data relevant to our study on the assumption that the derived demand for currency exchange emerges through the demand for exports or imports where order placement, production, and delivery entail a gestation period of probably more than a week.

Most previous studies have employed classical linear regression models and one-dimensional (time-series or cross-sectional) data, which have been unable to record the significant effect of exchange rate volatility on trade. This is considered a subjective limitation: when two-dimensional (panel) data and various models or estimation techniques (such as fixed effects or random effects) have been applied, the impact of exchange rate volatility proves to be significant but generally negative (Hondroyiannis, Swami, Tavlas, \& Ulan, 2005, p. 5). This problem drives further exploration of the relationship between volatility and trade and a chance to determine the most suitable estimation technique and compatible data frequency to reach a more conclusive result.

Several studies have also employed the US dollar as a base for calculating foreign currency-valued exchange rates to analyze financial aspects of international trade. However, no other study has used two different currency bases to calculate and compare exchange rates in the context of volatility impacts on trade. Such a study would need to choose between domestic currency-based direct exchange rates and foreign 
currency-based indirect exchange rates so as to avoid financial market distortions, which would otherwise disturb trade flows as well.

To partially fill this gap, we apply two-dimensional exchange rates: the "per unit USD" as the foreign currency-valued (indirect) exchange rate and the "per unit PKR" as the domestic currency-valued (direct) exchange rate. This will allow us to compare the risk involved in using the "domestic currency" instead of the "vehicle currency" in the context of trade stability and growth with respect to Pakistan's trading partners. Moreover, speculative attacks in currency markets, US policy, and the artificial hoarding of dollars can distort foreign currency-valued exchange rates by instigating volatile behavior. The rationale for using these in international transactions among developing countries thus needs to be re-evaluated.

Earlier studies have widely tested time-series and cross-sectional data. The recent focus on panel data estimation techniques attempts to overcome the limitations imposed by time-series and cross-sectional data when applied independently of each other. A pool of 29 cross-sections with time-series data containing up to 480 observations would permit us to explore the existence of country-wise fixed effects. Further, the application of panel estimation techniques or fixed-effects models (i.e., least-squares dummy variable [LSDV] estimators) is an effective technique when applied to the time dimension of panels, which are larger than cross-section dimensions because the dynamic panel mitigates the bias in the coefficient of estimates (Judson \& Owen, 1996). Five volatility variables have been derived using the most frequently tested GARCH-based specifications in terms of each currency for Pakistan's trading partners. ${ }^{1}$

Volatility emerges as a major issue when a flexible exchange rate regime replaces a fixed rate system. ${ }^{2}$ The State Bank of Pakistan has adopted different strategies to control exchange rate variations over the last four decades. The nominal exchange rate was fixed at approximately PRs 9.9/\$ from 1973 to 1981 , but a 14.8 percent devaluation occurred in the real exchange rate in 1982 when a managed-float exchange rate regime was adopted. In 1999, the State Bank ceased to announce the official exchange rate and the PKR-USD rate jumped from PRs 46/\$ to PRs 51.39/\$ (an 11.7 percent devaluation).

\footnotetext{
${ }^{1}$ GARCH (1,1), EGARCH, TGARCH, PGARCH, and CGARCH because many studies have recurrently employed these models in various situations. See, for example, Floros (2008); Siddiqui (2009); Irfan, Irfan, and Awais (2010); Pattichis (2003); Crowley and Lee (2003); Kemal (2005); Qayyum and Kemal (2006); Hayakawa and Kimura (2008); Adjasi, Harvey, and Agyapong (2008).

${ }^{2}$ However, real exchange rate volatility was an important issue even before 1970 and onward.
} 
In 2000, the rupee became fully flexible: as a result, the exchange rate rose once again from PRs 51.79/\$ to PRs 58.44/\$. In the last quarter of the year, rupee-dollar parity rose to PRs 64/\$-a 12.84 and 9.51 percent devaluation, respectively (i.e., a 23.56 percent loss in the value of the rupee against the dollar). Finally, post-September 2001, the rupee showed some appreciation. The volatility of the nominal exchange rate increased with the rising exchange rate (depreciation), but remained low or declined when the exchange rate appreciated. This could imply that depreciation caused higher instability and appreciation stabilized the exchange rates (Azid et al., 2005). Pakistan's share in world imports has ranged from a minimum of 0.12 percent in 1980 to a maximum of 0.18 percent in 1992. In 2002/03, it was 0.17 percent, suggesting that Pakistan's export performance was influenced by the exchange rate volatility (Mustafa \& Nishat, 2005).

\section{Literature Review}

In international transactions, a vehicle foreign currency (usually the US dollar) is used to quote exchange rates and conduct trade transactions, as evident from the fact that, till 1992, the recorded global currency turnover was 80 percent in dollar terms and exchange rates, among other currencies, were determined by their respective values against the dollar (Isard, 1995).

Some studies have attempted to explore the impact of volatility on imports. Since devaluation restricted aggregate supply because of increasingly expensive import production units, wage indexation programs, and high-cost working capital, the potential for trade has been lowered (see, for example, Bruno, 1979; Gylfason \& Schmid, 1983; Hanson, 1983; Gylfason \& Risager, 1984; Islam, 1984; Gylfason \& Radetzki, 1985; Branson, 1986; Solimano, 1986; van Wijnbergen, 1986; Edwards, 1989).

Many studies have investigated the impact of volatility on exports: Franke (1991) and Sercu and Vanhulle (1992) find that an increase in exchange rate volatility increases the value of exporting firms and thus promotes export activities. Broll and Eckwert (1999) observe that exchange rate volatility increases the option to export to the world market because of the higher potential gains from international trade for risk seekers. Other studies show that higher volatility leads to more gains from international trade (see Brada \& Méndez, 1988; Sercu \& Vanhulle, 1992; De Grauwe, 1994). 
Chowdhury (1993) investigates the impact of exchange rate volatility on the trade flows of the G-7 countries in the context of a multivariate error correction model. He observes a significant negative impact on export volume for each country. Prasad, Rogoff, Wei, and Kose (2004) find that "volatility has detrimental effects on international trade and thus has a negative economic impact, especially on emerging economies where underdeveloped capital markets and unstable economic policies exist."

Côté (1994) argues that exchange rate volatility has direct and indirect negative effects on international trade through uncertainty, adjustment costs, the allocation of resources, and government policies. A report by the Commission of the European Communities (1990) states that "the reduction of exchange rate uncertainty is necessary to promote intraEU trade and investment." Dell'Ariccia (1999) finds that increased exchange rate volatility has had a small but significant impact on trading among 15 European Union members where the reduction in volatility to zero allowed them to expand their trade by 3-4 percent.

Rose (2000) also finds a significant but inverse relationship between trade and exchange rate volatility, with up to a 13 percent loss in trade in response to a one-standard deviation rise in volatility. Using a fixed-effects model, Clark, Tamirisa, and Wei (2004) produce the same evidence but find a 7 percent loss in trade consequent to increased volatility equal to one standard deviation. Tenreyro's (2007) results are in line with these studies but indicate a 2 percent rise in trade with the total elimination of volatility. The stability of exchange rates may be disturbed when the foreign currency-valued exchange rate is used: Cushman (1986) identifies the presence of a "third-country effect" and argues that the impact of exchange rate variability on bilateral trade flows is not only dependent on the exchange rate risk experienced by the country under consideration, but also on its correlation with exchange rate fluctuations in other countries.

As Table 1 shows, the literature on the impact of the exchange rate on trade can be categorized in terms of importance as follows:

- $\quad$ Pronounced negative effect (Debate 2)

- Absolutely no effect or, if it exists, not obviously significant (Debate 4)

- Pronounced positive effect on trade flows and volume (Debate 1)

- Pronounced mixed (both positive and negative) effect (Debate 3) 
The most important consideration with regard to exchange rate volatility is the pronounced "negative" effect on trade because this can reduce the potential to expand trade. However, the existence of a significant "positive" effect would be surprising because, in such a situation, increased risk and variation in the exchange rate and other financial variables would ensure trade expansion.

In the literature on Pakistan, Amor and Sarkar (2008) find that openness helps reduce real exchange rate fluctuations. However, the framework of financial integration in South Asian and Southeast Asian countries does not favor the stability of the real exchange rate. Mustafa and Nishat (2004) analyze the effect of the exchange rate on export growth and find that volatility has a significantly negative effect with respect to major trading partners such as the UK and US. The volume of trade remains comparatively consistent and less volatile with respect to Australia, Bangladesh, and Singapore. There are long-run effects in the case of India but no empirical relationship with reference to New Zealand and Malaysia. 


\section{Table 1: Exchange rate volatility vs. trade: Conclusions based on empirical studies}

\begin{tabular}{|c|c|}
\hline Conclusion & Empirical studies with frequency of data and type of analysis \\
\hline $\begin{array}{l}\text { Debate } 1 \\
\text { Significant } \\
\text { positive } \\
\text { impact on } \\
\text { trade }\end{array}$ & $\begin{array}{l}\text { Studies: Broll and Eckwert (1999); Brada and Méndez (1988); } \\
\text { Asseery and Peel (1991); McKenzie and Brooks (1997); McKenzie } \\
\text { (1998); Kasman and Kasman (2005); Hwang and Lee (2005). } \\
\text { Methods (data frequency): cross-sectional (A), OLS-ECM (Q), OLS } \\
\text { (M), ARCH (Q), cointegration (Q), GARCH-M (M). } \\
\text { Cited in Kemal (2005, p. 3) and Ozturk (2006, table 1, p. 88). }\end{array}$ \\
\hline $\begin{array}{l}\text { Debate } 2 \\
\text { Significant } \\
\text { negative } \\
\text { impact on } \\
\text { trade }\end{array}$ & $\begin{array}{l}\text { Studies: Cushman (1983, 1986, 1988); Akhtar and Hilton (1984); } \\
\text { Kenen and Rodrick (1986); Thursby and Thursby (1987); De Grauwe } \\
\text { (1988); Peree and Steinherr (1986, 1989); Koray and Lastrapes (1989); } \\
\text { Arize (1995); Kumar and Dhawan (1991); Pozo (1992); Persson and } \\
\text { Svensson (1989); Lanyi and Suss (1986); Edwards (1987); Baldwin } \\
\text { and Krugman (1989); Siddique and Salam (2000); Belenger et al. } \\
\text { (1988); Caballero and Corbo (1989); Bini Smaghi (1991); Feenstra and } \\
\text { Kendall (1991); Belenger et al. (1992); Savvides (1992); Chowdhury } \\
\text { (1993); Caporale and Dorodian (1994); Hook and Boon (2000); } \\
\text { Doganlar (2002); Vergil (2002); Das (2003); Baak (2004); Clark, } \\
\text { Tamirisa, and Wei (2004); Arize et al. (2005); Lee and Saucier (2005). } \\
\text { Methods (data frequency): OLS (Q, A), IVE (Q), GIVE (Q), VAR (M, } \\
\text { Q), ARCH-GARCH (Q), cross-sectional (A), joint estimation (M), EG } \\
\text { cointegration (Q), SD (Q), ADF, ECM, cointegration (Q), gravity } \\
\text { model (A). } \\
\text { Cited in Mustafa and Nishat (2004, p. 2), Kemal (2005, p. 2), and } \\
\text { Ozturk (2006, table 1, p .88). }\end{array}$ \\
\hline $\begin{array}{l}\text { Debate } 3 \\
\text { Significant } \\
\text { MIXED } \\
\text { impact }\end{array}$ & $\begin{array}{l}\text { Studies: Kumar (1992); Frenkel and Wei (1993); Kroner and } \\
\text { Lastrapes (1993); Daly (1998). } \\
\text { Methods (data frequency): SD (A), OLS (A), IVE (A), GARCH-M (M). } \\
\text { Cited in Ozturk (2006, p. 90). }\end{array}$ \\
\hline $\begin{array}{l}\text { Debate } 4 \\
\text { NO or } \\
\text { insignificant } \\
\text { impact on } \\
\text { trade }\end{array}$ & $\begin{array}{l}\text { Studies: Hooper and Kohlhagen (1978); Gotur (1985); Bailey, Tavlas } \\
\text { and Ulan (1986, 1987); Bailey and Tavlas (1988); Asseery and Peel } \\
\text { (1991); Medhora (1990); Akhtar and Hilton (1991); Kumar and } \\
\text { Dhawan (1991); Gagnon (1993); Aristotelous (2001); Tenreyro (2004); } \\
\text { Bayoumi (1996); Bacchetta and van Wincoop (1998); Devereux and } \\
\text { Engel (2002); Koray and Lastrapes (1989). } \\
\text { Methods (data frequency): OLS (Q, A), simulation analysis (Q), } \\
\text { gravity model (A). } \\
\text { Cited in Ozturk (2006, p. 88) and Kemal (2005, p. 2). }\end{array}$ \\
\hline
\end{tabular}

Note: $\mathrm{A}=$ annual, $\mathrm{Q}=$ quarterly, $\mathrm{M}=$ monthly data. Debates are numbered for authors' reference purpose only.

According to Kemal (2005), exchange rate instability affects exports positively and imports negatively, which improves the trade balance. Azid et al. (2005) obtain positive but insignificant results that do not support the 
position that excessive volatility has a pronounced effect on manufacturing production. Qayyum and Kemal (2006) show that returns in the foreign exchange market remain mean-reverting and are affected by the volatility of stock market returns in Pakistan's case. Arize, Malindretos, and Kasibhatla (2003) observe that exchange rate volatility has a significantly negative impact on exports, implying that risk-averse traders will contract their trade to minimize exposure to exchange rate risks.

The gaps in the literature are as follows. First, while imports and the trade balance have received little attention, they are often found to be pivotal to exchange rate markets in developing countries (which tend to be import-dependent). Second, in cases where the frequency of the time-series data used in time-series models is inconsistent with the latter's design, the estimation and consequent outcomes are subject to skepticism. Third, the "third-country effect" has been observed but not properly evaluated. Fourth, exchange rate values in terms of domestic and foreign currency have not been compared in the context of Pakistan or other developing countries and only marginally at the international level. This study is, therefore, an effort to address these issues and provide further evidence regarding the volatility impact on trade, especially for Pakistan.

Based on the discussion above, our objective of evaluating domestic and foreign currency-valued exchange rate volatilities for export and import demand functions can be hypothesized as follows:

- Hypothesis 1: Using an international (vehicle) currency to conduct international transactions can cause volatility in exchange rates.

- Hypothesis 2: The direction of the volatility impact depends on the nature of volatility measurement specifications.

- Hypothesis 3: Exchange rate volatility significantly discourages both exports and imports.

\section{Methodology}

This section describes the models and data used, as well as the estimation and verification procedures applied.

\subsection{The Basic Models}

The impact of exchange rate volatility on trade is measured using two functional forms: the real export demand function and the real import demand function. These models are determined using the following 
variables: domestic and international inflation, the consumer price index (CPI) (a proxy for the price of nontradable items), GDP (as a proxy for the manufacturing production index), foreign reserves, the shares price index as a proxy for business and consumer sentiments (Tang, 2012), domestic interest rates, interest rate differentials, ${ }^{3}$ real exchange rates (measured in terms of both values), the per-unit US dollar as the foreign rate and the perunit Pakistani rupee as the domestic rate, and GARCH-based exchange rate volatilities. Further, the corresponding autoregressive term allows us to capture the dynamic nature of these models and the speed at which they adjust toward long-run equilibrium in case a deviation occurs.

Since exports will decrease with an exchange rate appreciation while imports will rise, mathematically, this relation is given as

$$
\begin{aligned}
& X=\mathrm{f}[1 /(E R \text { per } \$)] \\
& M=\mathrm{f}(E R \text { per } \$)
\end{aligned}
$$

Real exports $(R X)$ and real imports $(R M)$ are calculated as follows, using data on the value of exports and imports in millions of domestic currency for each country and the price index:

$$
R X_{j}=\left[\frac{\frac{X_{j}}{e r^{*}}}{C P I^{U S}}\right]=X_{j}^{U S D} / C P I^{U S} \text { and } R M_{j}=\left[\frac{\frac{M_{j}}{e r^{*}}}{C P I^{U S}}\right]=M_{j}^{U S D} / C P I^{U S}
$$

where $R M_{j}=$ the real exports of the $j$ th country in USD terms, $X_{j}^{U S D}=$ the real imports of the $j$ th country in USD terms, = the nominal exports of the $j$ th country in USD terms, $M_{j}^{U S D}=$ the nominal imports of the $j$ th country in USD terms, $C P I^{U S}=$ the US Consumer Price Index $(\mathrm{CPI})$, and $e r^{*}=$ monthly average exchange rates (domestic currency per unit of USD).

The real exchange rate in terms of the domestic currency per unit of foreign currency will be a function of the nominal exchange rate and the foreign-to-domestic price ratio $(P f / P d)$ for each country:

$$
R E R=\mathrm{f}\left(P^{d}, P f, N E R\right)
$$

To calculate the real exchange rate in both USD and PKR terms, we use the methods below:

\footnotetext{
${ }^{3}$ The difference between the domestic interest rate and selected international interest rates.
} 


$$
\begin{aligned}
& R E R D_{j}=\prod_{j=1}^{m} N E R_{j}^{d c r / U S D}\left[\frac{C P I^{U S}}{C P I_{j}}\right] \text { and } \\
& R E R R_{j}=\prod_{j=1}^{m} N E R_{j}^{d c r / P K R}\left[\frac{C P I^{P K}}{C P I_{j}}\right]
\end{aligned}
$$

where $R E R D_{j}$ = the real exchange rate in foreign currency terms (USD) for country $j, R E R R_{j}=$ the real exchange rate in domestic currency terms (PKR) for country $j, C P I_{j}=$ the CPI of country $j, C P I^{U S}=$ the CPI of the US, $C P I^{P K}$ = the CPI of Pakistan, $m=$ the total number of countries in the sample, $N E R_{j}^{d c r / U S D}=$ the nominal exchange rate (monthly average) of country $j$ in terms of domestic currency per unit USD, $N E R_{j}^{d c r / P K R}=$ the nominal exchange rate (monthly average) of country $j$ in terms of domestic currency per unit PKR.

\subsection{Model Specification}

GARCH models are assumed to be appropriate for capturing news elements ${ }^{4}$ in time-series data. They also help us understand the dynamic behavior of exchange rate variables and derive variance series for volatility. The real exchange rate usually depends on its values in the recent past and on the nonconstant variance, hence:

$$
R E R=\mathrm{f}\left[R E R_{t-1}, u_{\mathrm{t}} \sim N\left(0, h^{2}\right)\right]
$$

Accordingly, the impact of autoregressive and autocorrelation elements to the exchange rate is accounted for through the first lag of the dependent variable and error terms, respectively. However, the conditional constraint $u_{\mathrm{t}}\left(h^{2}\right)$ indicates that any shock or noise that might exist in the error term $\left(u_{t}\right)$ is normally distributed with a zero mean and nonconstant variance $\left(h^{2}\right)^{\prime}$. The export and import demand functions are expressed below.

\subsubsection{Real Export Demand Function}

The real export demand function is

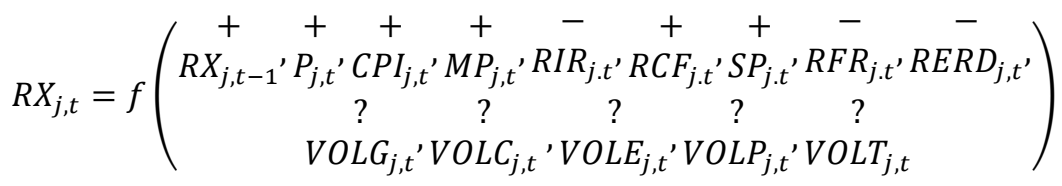

\footnotetext{
${ }^{4}$ For reference purposes, this is equivalent to innovation, noise, or shock.
} 


\subsubsection{Real Import Demand Function}

The real import demand function is

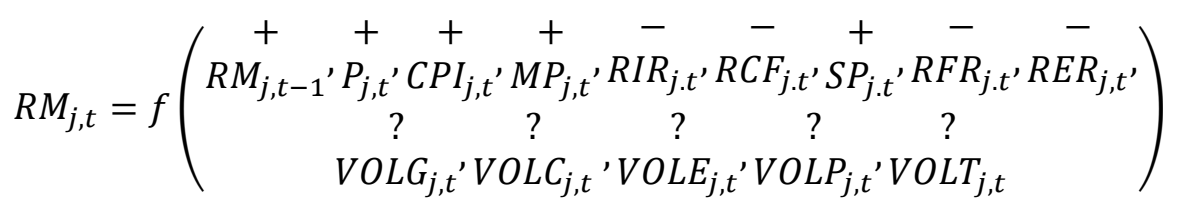

where $R X_{j, t}=$ the demand for real exports of country $j$ at time $t$ (current period), $R X_{j, t-1}=$ the demand for real exports of country $j$ at time $t-1$ (previous period), $R M_{j, t}=$ the demand for real imports of country $j$ at time $t, R M_{j, t-1}=$ the demand for real imports of country $j$ at time $t-1, P_{j, t}=$ the inflation rate of country $j$ at time $t, C P I_{j, t}=$ the CPI of country $j$ at time $t$, $M P_{j, t}=$ the manufacturing production of country $j$ at time $t, R F R_{j . t}=$ the real foreign reserves of country $j$ at time $t, R I R_{j . t}=$ the real interest rate of country $j$ at time $t, R C F_{j . t}=$ the real (net) capital (out)flows of country $j$ at time $t, S P_{j . t}=$ the shares price index of country $j$ at time $t, R E R_{j, t}=$ the real exchange rate of country $j$ at time $t, V O L G_{j, t}=$ the GARCH-based exchange rate volatility of country $j$ at time $t, V O L C_{j, t}=$ the CGARCH-based exchange rate volatility of country $j$ at time $t, V O L E_{j, t}=$ the EGARCH-based exchange rate volatility of country $j$ at time $t, V O L P_{j, t}=$ the nonlinear GARCH-based exchange rate volatility of country $j$ at time $t, V O L T_{j, t}=$ the TGARCH-based exchange rate volatility of country $j$ at time $t$.

Theoretically, the income level has a positive and direct association with exports and imports while the inflation rate $(P)$ has an inverse association with exports and imports through exchange rate adjustment. Real foreign reserves (RFR) are accumulated through the export of goods and services (possibly with some lag) but they deteriorate with imports. A rise in the shares price index encourages trading activities, while rising interest rates will discourage investment, exports, and imports. Real capital (out) flows will encourage exports and imports subject to some constraints. An appreciation (depreciation) in the real exchange (domestic) rate will increase (decrease) imports and reduce (raise) exports, with the reverse for the foreign rate. Exchange rate volatility may have a four-dimensional impact on exports and imports (see Table 1). 
Table 2: List of relevant variables

\begin{tabular}{ll}
\hline $\begin{array}{l}\text { Variables of } \\
\text { interest }\end{array}$ & $\begin{array}{l}\text { Real exports, real imports, first lag of real exports and imports, } \\
\text { nominal and real exchange rate, various volatility specifications. }\end{array}$ \\
$\begin{array}{l}\text { Control } \\
\text { variables }\end{array}$ & $\begin{array}{l}\text { Cross-country political and structural differences, inflation rate, } \\
\text { prices of nontradable commodities, production level, real } \\
\text { foreign reserves, real capital flows, real interest rates, shares } \\
\text { price index. }\end{array}$ \\
\hline
\end{tabular}

\subsubsection{Real Export Demand Equation}

We employ double-log models in our estimation to overcome the problem of nonstationarity detected in some variables, which need to be dealt with cautiously:

$$
\begin{aligned}
& L N R X_{j, t}=\beta_{0}+\sum_{i=1}^{n} \beta_{1, i} L N R X_{j, t-1}+\sum_{i=0}^{n} \beta_{2, i} L N P_{j, t}+\sum_{i=0}^{n} \beta_{3, i} L N C P I_{j, t}+ \\
& \sum_{i=0}^{n} \beta_{4, i} L N M P_{j, t}+\sum_{i=0}^{n} \beta_{5, i} L N R F R_{j, t}+\sum_{i=0}^{n} \beta_{6, i} L N R I R_{j, t}+ \\
& \sum_{i=0}^{n} \beta_{7, i} L N S P_{j, t}+\sum_{i=0}^{n} \beta_{8, i} L N R C F_{j, t}^{2}+\sum_{i=0}^{n} \beta_{9, i} L N R E R_{j, t}+ \\
& \sum_{i=0}^{n} \beta_{10, i} L N V O L G_{j, t}+\sum_{i=0}^{n} \beta_{11, i} L N V O L E_{j, t}+\sum_{i=0}^{n} \beta_{12, i} L N V O L T_{j, t}+ \\
& \sum_{i=0}^{n} \beta_{13, i} L_{1 N V O L P_{j, t}}+\sum_{i=0}^{n} \beta_{14, i} L N V O L C_{j, t}+u_{j, t}+v_{j, t}
\end{aligned}
$$

Taking the first difference of each variable in the suggested model allows us to make a short-run analysis as well:

$$
\begin{aligned}
\Delta \mathrm{RX}_{\mathrm{j}, \mathrm{t}}= & \beta_{0}+\beta_{1} \Delta \mathrm{RX}_{\mathrm{j}, \mathrm{t}-1}+\beta_{2} \Delta \mathrm{P}_{\mathrm{j}, \mathrm{t}}+\beta_{3} \Delta \mathrm{CPI}_{\mathrm{j}, \mathrm{t}}+\beta_{4} \Delta \mathrm{MP}_{\mathrm{j}, \mathrm{t}}+\beta_{5} \Delta \mathrm{RFR}_{\mathrm{j}, \mathrm{t}}+ \\
& \beta_{6} \Delta \mathrm{RIR}_{\mathrm{j}, \mathrm{t}}+\beta_{7} \Delta \mathrm{SP}_{\mathrm{j}, \mathrm{t}}+\beta_{8} \Delta \mathrm{RCF}_{\mathrm{j}, \mathrm{t}}+\beta_{9} \Delta \mathrm{RER}_{\mathrm{j}, \mathrm{t}}+\beta_{10} \Delta \mathrm{VOLG}_{\mathrm{j}, \mathrm{t}}+ \\
& \beta_{11} \Delta \mathrm{VOLE}_{\mathrm{j}, \mathrm{t}}+\beta_{12} \Delta \mathrm{VOLT}_{\mathrm{j}, \mathrm{t}}+\beta_{13} \Delta \mathrm{VOLP}_{\mathrm{j}, \mathrm{t}}+\beta_{14} \Delta \mathrm{VOLC}_{\mathrm{j}, \mathrm{t}}+\Delta v_{\mathrm{j}, \mathrm{t}}
\end{aligned}
$$

\subsubsection{Real Import Demand Equation}

Having considered all the factors that might determine the export demand for domestic output, it is equally important to determine the import demand for internationally available foreign output, although the nature of this relationship may vary:

$$
\begin{aligned}
\text { LNRM }_{j, t} & = \\
& \beta_{0}+\sum_{i=1}^{n} \beta_{1, i} L N R M_{j, t-1}+\sum_{i=0}^{n} \beta_{2, i} L N P_{j, t}+\sum_{i=0}^{n} \beta_{3, i} L N C P I_{j, t}+ \\
& \sum_{i=0}^{n} \beta_{4, i} L N M P_{j, t}+\sum_{i=0}^{n} \beta_{5, i} L N R F R_{j, t}+\sum_{i=0}^{n} \beta_{6, i} L N R I R_{j, t}+ \\
& \sum_{i=0}^{n} \beta_{7, i} L N S P_{j, t}+\sum_{i=0}^{n} \beta_{8, i} L N R C F_{j, t}^{2}+\sum_{i=0}^{n} \beta_{9, i} L N R E R_{j, t}+ \\
& \sum_{i=0}^{n} \beta_{10, i} L N V O L G_{j, t}+\sum_{i=0}^{n} \beta_{11, i} L N V O L E_{j, t}+ \\
& \sum_{i=0}^{n} \beta_{12, i} L_{N V O L T_{j, t}}+\sum_{i=0}^{n} \beta_{13, i} L N V O L P_{j, t}+ \\
& \sum_{i=0}^{n} \beta_{14, i} L_{N V O L C}+t+u_{j, t}+v_{j, t}
\end{aligned}
$$


For a short-run analysis, the equation can be written as

$$
\begin{aligned}
\Delta \mathrm{RM}_{\mathrm{j}, \mathrm{t}}= & \beta_{0}+\beta_{1} \Delta \mathrm{RM}_{\mathrm{j}, \mathrm{t}-1}+\beta_{2} \Delta \mathrm{P}_{\mathrm{j}, \mathrm{t}}+\beta_{3} \Delta \mathrm{CPI}_{\mathrm{j}, \mathrm{t}}+\beta_{4} \Delta \mathrm{MP}_{\mathrm{j}, \mathrm{t}}+\beta_{5} \Delta \mathrm{RFR}_{\mathrm{j}, \mathrm{t}}+ \\
& \beta_{6} \Delta \mathrm{RIR}_{\mathrm{j}, \mathrm{t}}+\beta_{7} \Delta \mathrm{SP}_{\mathrm{j}, \mathrm{t}}+\beta_{8} \Delta \mathrm{RCF}_{\mathrm{j}, \mathrm{t}}+\beta_{9} \Delta \mathrm{RER}_{\mathrm{j}, \mathrm{t}}+\beta_{10} \Delta \mathrm{VOLG}_{\mathrm{j}, \mathrm{t}}+ \\
& \beta_{11} \Delta \mathrm{VOLE}_{\mathrm{j}, \mathrm{t}}+\beta_{12} \Delta \operatorname{VOLT}_{\mathrm{j}, \mathrm{t}}+\beta_{13} \Delta \mathrm{VOLP}_{\mathrm{j}, \mathrm{t}}+\beta_{14} \Delta \mathrm{VOLC}_{\mathrm{j}, \mathrm{t}}+\Delta v_{\mathrm{j}, \mathrm{t}}
\end{aligned}
$$

The logarithmic transformation makes the series stationary in most cases (see Table A1 in the Appendix) and allows us to make a comparative analysis of functional relationships and the elasticities of the given variables. Differenced equations ensure the stationarity of each variable in

\begin{tabular}{|c|c|c|}
\hline $\begin{array}{l}\text { Volatility } \\
\text { proxy }\end{array}$ & $\begin{array}{c}\text { Elements captured in } \\
\text { 'news' component }\end{array}$ & Explanation \\
\hline GARCH & Volatility clustering & $\begin{array}{l}\text { Helps quantify impact of any shock on variance } \\
\text { that continues to transmit itself during adjacent } \\
\text { time interval, as a large shock is followed by a } \\
\text { larger one and a small shock is followed by a } \\
\text { smaller one. However, shock transmission } \\
\text { process is captured by nonlinear specifications. }^{\text {a }}\end{array}$ \\
\hline EGARCH & $\begin{array}{l}\text { Leverage effect, } \\
\text { nature of dominant } \\
\text { shock }\end{array}$ & $\begin{array}{l}\text { Helps expose the shock, which may strongly } \\
\text { influence the variance because a "negative } \\
\text { shock" causes greater loss in returns than the } \\
\text { gains from a "positive shock." }\end{array}$ \\
\hline TGARCH & $\begin{array}{l}\text { Asymmetries in } \\
\text { news, impact of bad } \\
\text { news }\end{array}$ & $\begin{array}{l}\text { Measures the significance and proportional } \\
\text { contribution of negative shock that destabilizes } \\
\text { variance. }\end{array}$ \\
\hline CGARCH & $\begin{array}{l}\text { Long-run persistence } \\
\text { (of news) in volatility } \\
\text { patterns }\end{array}$ & $\begin{array}{l}\text { Reflects the consistency of shock impact in } \\
\text { variance series, which may not allow the } \\
\text { variance to become stable over time. }\end{array}$ \\
\hline $\begin{array}{l}\text { NGARCH } \\
\text { (PGARCH) }\end{array}$ & $\begin{array}{l}\text { Nonlinearities and } \\
\text { asymmetries }\end{array}$ & $\begin{array}{l}\text { Allows us to capture the degree of correlation } \\
\text { between current and lagged observations of the } \\
\text { time series in absolute and squared terms; } \\
\text { remains significantly positive for very long lags. }\end{array}$ \\
\hline
\end{tabular}
the model but at the expense of dynamic long-run effects.

Table 3: Description of volatility specifications

Source: $\mathrm{a}=$ Clements (2005, p. 64) and Islam (2004, p. 133); b = Islam (2004, p. 133).

\subsection{Data Specification}

Our major source of data is the International Financial Statistics database. Data on bilateral exports is taken from the Direction of Trade Statistics database. We have selected monthly data series from January 1970 to December 2009, covering 40 years with up to 480 values for each 
time-series variable, especially in the case of all exchange rates. However, to account for any missing values, we have also consulted the Penn World Tables (Version 6.1; see Heston, Summers, \& Aten, 2002) and the official websites of the sampled countries, especially in relation to their statistical bureaus and central banks.

\subsection{Estimation Procedure}

We capture the dynamic relationship in question by estimating LSDV fixed-effects models, using a panel data approach and a sample of 29 trading partners (of Pakistan) that hold significant trade shares (see Table $\mathrm{C} 1$ in the Appendix). Although various estimation techniques have been employed in similar studies (see Table 1), cross-sectional and time-series data can pose problems. As Dell'Ariccia (1999) points out, the unobservable cross-sectional-specific effects that usually influence trade flows (such as cross-country structural and policy differences) can only be captured through fixed-effects or random-effects specifications.

The dataset we have used has both a time-series $(\mathrm{T})$ and crosssectional $(\mathrm{N})$ dimension (with the condition $\mathrm{N}>\mathrm{T}$ where $\mathrm{T}$ is large). This is referred to as panel or longitudinal data. In comparing the asymptotic variances, it is obvious that, although less biased, simple instrumental variable estimators yield substantial efficiency losses compared to the LSDV (and GMM) techniques (Bun, 2001).

\subsection{Panel Unit Root Tests}

Our analysis employs monthly data series for 29 countries, ranging from 1970:01 to 2009:12. To avoid spurious estimates, we apply three different panel unit root tests (where the first two are given more weight than the third): (a) Levin, Lin, and Chu (LLC); (b) Im, Pesaran, and Shin (IPS); and (c) Hadri Lagrange multiplier (HLM).

The LLC and HLM tests both assume common transverse crosssectional persistence parameters, i.e., identical autoregressive coefficients, while the IPS test allows these autoregressive coefficients to vary freely across cross-sections (Quantitative Micro Software, 2007). The LLC test evaluates the null hypothesis of a common unit root while the IPS test considers individual unit roots. The results (Table A1 in the Appendix) show that, according to both the LLC and IPS criteria, all variables at level remain stationary at a 1 percent level of significance except real exports, real imports, the inflation rate, consumer prices, productivity, the ordinary 
and $\log$ of the stock of real foreign reserves, and shares prices. However, the real capital flow variable is nonstationary at level based on the LLC criterion. These nonstationary variables became stationary either by transforming them into logarithmic form or taking their first difference.

The probable limitation of the HLM is "the over-rejection of the null hypothesis due to high autocorrelation," which can cause severe size distortions. ${ }^{5}$ Accordingly, it is possible that those variables that proved to be stationary at level (based on the LLC and IPS tests) might not remain stationary on applying the HLM test. We therefore consider the LLC and IPS tests to be better in evaluating the stationarity of the relevant variables.

\subsection{Hausman Test and Likelihood Ratio}

The Hausman test is used to detect random effects while the likelihood ratio examines fixed effects in panel data models. Both tests are applied to evaluate our cross-sectional fixed- and random-effects models. All equations are estimated using LSDV pooled and panel estimation techniques. The fixed-effects likelihood ratio allows us to reject the null hypothesis of redundant fixed effects due to the large value of the chisquared term. This implies that these models are best suited to fixed effects mainly when the cross-section weights limitation is imposed. ${ }^{6}$

\subsection{The Case for Fixed-Effects Modeling}

There are two types of variations: (i) inter-country (cross-sectional effects), which can be handled independently by cross-sectional models; and (ii) intra-country (period effects), which can be dealt with by timeseries models (see Dranove, n.d.). Panel data helps us handle both dimensions simultaneously. The availability of a large number of observations in this study allows us to determine the effect of the volatility component within each country in a sample by using a fixed-effects model.

The main purpose of fixed-effects modeling is to remove any bias caused by omitted variables. In the case of exchange rate variations, the omitted variables include: the diversification of risk-related behavior of traders and investors, country-wise differences in exchange rate markets, and the pattern of relationships among countries in the context of bilateral

\footnotetext{
${ }^{5}$ As observed in the results obtained through the application of EViews.

${ }^{6}$ Random effects were tested but did not remain valid on application of the autoregressive term in the suggested models.
} 
or multilateral trade arrangements. Fixed-effects models do this by exploiting temporal variations within groups.

\subsubsection{Specifications and Limitations of Fixed-Effects Estimation}

Each fixed-effects model was estimated using a pooled EGLS crosssection weights specification. The total number of unbalanced pool observations is more than 9,000. The specified limitation for obtaining the best-fit model includes cross-section weighted (PCSE) standard errors and covariance after correcting for the degree of freedom. First-differenced models effectively fit the limitation specified by cross-section SUR (PCSE) standard errors and covariance after degree of freedom correction.

However, the application of the short-run model reduces the sample, which started from 1992:01 to 2009:12. The values of the weighted adjusted R-squares range from 15 to 40 percent. Moreover, the square of real capital flows has to be taken in double-log models to allow all values of the series to remain intact (which might otherwise be lost in log transformations because of frequent negative values).

Technically, a bias may emerge when estimating fixed-effects panel models due to the presence of lag terms in the given equations. However, the fixed-effects $u_{j, t}$ is removed when variables are used by taking the first difference in the model.

\section{Results, Analysis, and Discussion}

This section describes the short- and long-run volatility impact on the trade functions.

\subsection{Long-Run Volatility Impact}

The results obtained from the fixed-effects log models show that exchange rate volatility has a highly significant impact on both the real import and export demand functions. While all the sampled countries were evaluated, the magnitude of the impact and the number of significant volatility variables are larger for the foreign currency rate than the domestic rate at a 5 percent level of significance. In particular, the impact of the GARCH-based volatility variables on trade depends on the nature of volatility in the exchange rate measured by each corresponding volatility variable. 
Interestingly, no volatility variable is significant at the 5 percent level of significance-and very few at the 10 percent level-when developed countries are excluded from the sample and the domestic currency is taken as the mode of transaction. Moreover, the use of foreign currency-based exchange rates in this sub-sample ensures strictly that the volatility influence exists, which implies that trade among developing countries will be significantly affected by high margins of volatility when the foreign currency replaces the domestic currency as a base for measuring exchange rates and executing trade transactions.

The GARCH $(1,1)$ model allows us to record volatility clustering: this is significant in both the export and import functions in terms of the domestic rate but only significant in the import function in terms of the foreign rate. All other volatility specifications are highly significant in terms of the foreign rate for the export demand function, except the CGARCH for imports.

Analyzing the full sample reveals that the impact of bad news is significant in the export function while a leverage effect is noted in the import function. The long-run persistence of news occurs in both functions. Remarkably, in the case of the developing countries subsample, all the volatility variables are insignificant except for nonlinearity in volatility, which is significant at the 10 percent level only in the import demand function. In both currency terms, the impact of bad news encourages exports in the long run when the sample countries' mutual trade links are accounted for. In the foreign currency rate, however, the same phenomenon discourages exports in the sub-sample and imports in both samples.

\subsection{Short-Run Volatility Impact}

The short-run analysis reveals that volatility has no significant effect on trade when Pakistan trades only with developing countries. The robustness of this finding is established when we evaluate the developed countries in the full sample as well as separately. Both results confirm the existence of a significant volatility effect. The direction of the volatility effect differs across volatility specifications. 


\subsection{Volatility Specification Impact}

Having established that the exchange rate volatility impact is significant, each model, based on a particular volatility specification, behaves differently.

- GARCH $(1,1)$ shows that shock disturbances continue to transmit their effect in subsequent periods and cause instability in trade flows and in the expected stream of returns. Therefore, volatility clustering depresses real exports persistently both in the long run ${ }^{7}$ and the short run when we consider all Pakistan's trading partners by using the vehicle currency. In contrast, when using the PKR in trade with underdeveloped partners, there is no volatility impact in either the short or long run. ${ }^{8}$ In the case of real imports, GARCH-based volatility significantly encourages imports in the short run when using a vehicle currency (foreign rate) and the domestic rate, but discourages imports in the long run (except, when among underdeveloped countries, imports are transacted using the domestic rate).

- The EGARCH-based leverage effect and dominant shocks lead to an increase in real exports when using the vehicle currency as a whole. However, in the short run, real exports decrease among underdeveloped partners and remain completely insignificant when using the domestic rate. In the short run, imports among all the sampled partners are encouraged in terms of both rates. However, among underdeveloped partners, we see no volatility effect on real imports when using the domestic rate; the effect significantly discourages imports in the short run and encourages them in the long run.

- TGARCH-based asymmetries and the impact of bad news discourage real exports among all partners when using the vehicle currency (foreign rate). This also applies in the long run to underdeveloped partners. Using the domestic rate encourages real exports in the long run only but with no effect otherwise. Real imports are discouraged among all partners but with no effect in the case of most underdeveloped partners when the domestic rate is considered.

- The CGARCH-based long-run persistence of news discourages real exports in both the long and short run when using the vehicle currency for all partners. However, when Pakistan trades with underdeveloped counterparts, real exports are encouraged in the short run but

\footnotetext{
${ }^{7}$ In line with the conclusions drawn by Arize et al. (2003).

${ }^{8}$ McKenzie (1999) reaches a similar conclusion.
} 
discouraged in the long run. Underdeveloped partners remain immune in domestic rate terms. Real imports are discouraged irrespective of the partner in the short run. In the long run, we see no effect except when the domestic rate is used (for all partners).

- NGARCH-based nonlinearities generally encourage real exports except among underdeveloped partners in the short run, which remains unaffected alike domestic rate in all cases except in short run when it encouraged real exports for all partners in short run. Real imports increase in the short run for all the sampled countries as well as in the long run within the underdeveloped partner sample. Otherwise, there is no effect.

\section{Conclusions and Policy Recommendations}

Our results imply that dependence on a vehicle currency (USD) can become a serious issue for developing countries trading with each other. When Pakistan relies on a vehicle currency for trade with all its sampled partners (irrespective of the type of country), volatility has a significant effect on trade. Imports in particular are discouraged (see Arize, 1998) in both the short and long run, based on the vehicle currency. Real exports are adversely affected by volatility among developing trade partners, at least in the short run as evidenced by Hayakawa and Kimura (2008) and Chit et al. (2008) for East Asian countries ${ }^{9}$ and earlier by Kumar and Dhawan (1991) for export demand in Pakistan.

Using the country's own currency to conduct trade transactions by excluding the developed trade partners helps avoid volatility distortions. This implies that the volatility impact may emerge when considering trade with developed trade partners and when the foreign currency is involved. ${ }^{10}$ These results are in line with Esquivel and Larraín (2002) and Mustafa and Nishat (2004). We can conclude that volatility might not reside purely in the vehicle currency but can also be transmitted from developed countries' financial markets through trade links. Hence, we can justify the first hypothesis and provide evidence on the existence of Cushman's third-country effect.

On average, most exchange rate volatility variables remain significant when the vehicle currency is employed to conduct international

\footnotetext{
${ }^{9}$ This is because most of the developing countries in our selected sample belong to East Asia.

${ }^{10}$ Supported by the estimation results obtained for the sub-sample of developed trade partners (not reported here due to limited space but available on request).
} 
transactions related to real exports among all the sampled partners. However, when only underdeveloped partners and the domestic rate are considered, volatility has no effect on real exports. Further, the magnitude and direction of the impact is volatility specification-dependent. Exchange rate volatility also affects real imports whether among all sampled partners or only among underdeveloped partners. However, volatility appears to have no impact when the domestic rate is employed for import transactions with underdeveloped partners. Hence, the first hypothesis holds.

Both real exports and real imports experience a mixed effect with respect to GARCH-based volatility: a continuing shock element encourages trade in the short run but can affect it adversely or not at all in the long run. EGARCH- and NGARCH-based volatilities (i.e., the leverage effect of a dominant shock as well as nonlinear patterns in volatility) have a positive and direct effect that encourages trade. The negative and inverse effect of TGARCH- and CGARCH-based volatilities implies that bad news and the persistence of a shock can both damage trade. Showing that the volatility impact depends on the nature of the volatility specification justifies the second hypothesis. The results also provide evidence in favor of the third hypothesis by showing that exchange rate volatility has a similar impact on both real exports and real imports.

On the whole, our results show that the adverse impact of volatility can be avoided by trading mainly with emerging and developing countries (middle-income and lower middle-income groups, respectively) and by conducting bilateral trade in their own currencies rather than using a vehicle currency. These results have important implications for Pakistan, where trade is concentrated in only a few countries. Policymakers need to explore potential opportunities that would increase trade openness by expanding Pakistan's trade with other countries.

The results deviate from Hayakawa and Kimura (2008) perhaps because we have used domestic currency-based exchange rates. However, like Pakistan, a large number of developing countries have trade concentrations with developed countries (see Table C1 in the Appendix). A recent economic survey suggests that the global economy is passing from a unipolar (US) economy toward multi-polar (emerging) economies (Pakistan Economic Survey, 2010-11). This means that, in the future, such structural changes in trade patterns may help avoid potential volatility distortions. 
Finally, Pakistan clearly needs to revise its trade policy and expand trade with low- and middle-income developing and emerging economies, using its own domestic currency to avoid the uncertainties and related instability of exchange rates. These uncertainties can emerge through the use of international currency in bilateral trade transactions because a variety of latent patterns in exchange rate volatility are potentially channeled through the vehicle currency.

The same model could be re-estimated on a regional basis to explore the potential for regional integration. In addition, assessing the use of other developing countries' currencies as a base for executing international trade would not only help compare the volatility impact with that of the vehicle currency, but also allow developing countries to circumvent potential distortions that might be transmitted through the financial markets of developed countries. 


\section{References}

Adjasi, C., Harvey, S. K., \& Agyapong, D. (2008). Effect of exchange rate volatility on the Ghana Stock Exchange. African Journal of Accounting, Economics, Finance and Banking Research, 3(3), 28-47.

Aliyu, S. U. R. (2008). Exchange rate volatility and export trade in Nigeria: An empirical investigation (MPRA Paper No. 13490). Munich: University Library of Munich.

Amor, T. H., \& Sarkar, A. U. (2008). Financial integration and real exchange rate volatility: Evidences from South and South East Asia. International Journal of Business and Management, 3(1), 112-124.

Andersen, T., Bollerslev, T., Diebold, F. X., \& Labys, P. (2001). The distribution of realized exchange rate volatility. Journal of the American Statistical Association, 96, 42-55.

Arize, C. A. (1998). The effect of exchange rate on US imports: An empirical investigation. International Economic Journal, 12(3), 31-40.

Arize, C. A., Malindretos, J., \& Kasibhatla, K. M. (2003). Does exchangerate volatility depress export flows: The case of LDCs. International Advances in Economic Research, 9(1), 7-19.

Azid, T., Jamil, M., \& Kousar, A. (2005). Impact of exchange rate volatility on growth and economic performance: A case study of Pakistan, 1973-2003. Pakistan Development Review, 44(4, Pt. II), 749-775.

Bahmani-Oskooee, M. (2002). Does black market exchange rate volatility deter the trade flows? Iranian experience. Applied Economics, 34(18), 2249-2255.

Beine, M., Lahaye, J., Laurent, S., Neely, C. J., \& Palm, F. C. (2006). Central bank intervention and exchange rate volatility, its continuous and jump components (Working Paper No. 2006-031B). St. Louis, MO: Federal Reserve Bank of St. Louis.

Bénassy-Quéré, A., Fontagné, L., \& Lahrèche-Révil, A. (2001). Exchange-rate strategies in the competition for attracting foreign direct investment. Journal of Japanese and International Economies, 15, 178-198. 
Berger, H., Sturm, J.-E., \& de Haan, J. (2000). An empirical investigation into exchange rate regime choice and exchange rate volatility (Working Paper No. 263). Munich: Center for Economic Studies, Ifo Institute.

Brada, J. C., \& Méndez, J. A. (1988). Exchange rate risk, exchange rate regime, and the volume of international trade. Kyklos, 41(2), 263-280.

Branson, W. H. (1986). Stabilization, stagflation, and investment incentives: The case of Kenya, 1979-1980. In S. Edwards \& L. Ahamed (Eds.), Economic adjustment and exchange rates in developing countries (pp. 267-293). Chicago, IL: Chicago University Press.

Broll, U., \& Eckwert, B. (1999). Exchange rate volatility and international trade. Southern Economic Journal, 66(1), 178-185.

Brooks, C. (2008). Introductory econometrics for finance (2nd ed.). Cambridge: Cambridge University Press.

Bruno, M. (1979). Stabilization and stagflation in a semi-industrialized economy. In R. Dornbusch \& J. Frenkel (Eds.), International economic policy. Baltimore, MD: Johns Hopkins University Press.

Buddelmeyer, H., Jensen, P. H., Oguzoglu, U. \& Webster, E. (2008). Fixed effects bias in panel data estimators (Discussion Paper No. 3487). Bonn, Germany: Institute for the Study of Labor.

Bun, M. J. G. (2001). Accurate statistical analysis in dynamic panel data models. PhD thesis, Tinbergen Institute, Amsterdam.

Canales-Kriljenko, J., \& Habermeier, K. (2004). Structural factors affecting exchange rate volatility: A cross-section study (Working Paper No. 04/147). Washington, DC: International Monetary Fund.

Chit, M. M., Rizov, M., \& Willenbockel, D. (2008). Exchange rate volatility and exports: New empirical evidence from the emerging East Asian economies (Economics and Statistics Discussion Paper No. 127). London: Middlesex University.

Chowdhury, A. R. (1993). Does exchange rate volatility depress trade flows? Evidence from error-correction models. Review of Economics and Statistics, 75(4), 700-706. 
Clark, P., Tamirisa, N., \& Wei, S.-J. (2004). A new look at exchange rate volatility and trade flows (Occasional Paper No. 235). Washington, DC: International Monetary Fund.

Clements, M. P. (2005). Evaluating econometric forecasts of economic and financial variables. Basingstoke: Palgrave Macmillan.

Commission of the European Communities. (1990). One market, one money: An evaluation of potential benefits and costs of forming an economic and monetary union (European Economy No. 44). Brussels: Author.

Côté, A. (1994). Exchange rate volatility and trade: A survey (Working Paper No. 94-5). Ottawa, ON: Bank of Canada.

Crowley, P., \& Lee, J. (2003). Exchange rate volatility and foreign investment: International evidence. International Trade Journal, 17(3), 227-252.

Cushman, D. O. (1986). Has exchange risk depressed international trade? The impact of third-country exchange risk. Journal of International Money and Finance, 5(3), 361-379.

De Grauwe, P. (1994). The economics of monetary integration. New York, NY: Oxford University Press.

Dell'Ariccia, G. (1999). Exchange rate fluctuations and trade flows: Evidence from the European Union. IMF Staff Papers, 46(3), 315-334.

Dranove, D. (n.d.). Fixed effects models [Lecture notes]. Kellogg School of Management, Northwestern University. Retrieved from www.kellogg.northwestern.edu/faculty/dranove/htm/dranove/ coursepages/Mgmt\%20469/Fixed\%20Effects\%20Models.pdf

Edwards, S. (1989). Real exchange rates, devaluation, and adjustments. Cambridge, MA: MIT Press.

Esquivel, G., \& Larraín, B. F. (2002). The impact of G-3 exchange rate volatility on developing countries (G-24 Discussion Paper No. 16). Geneva: United Nations Conference on Trade and Development.

Floros, C. (2008). Modeling volatility using GARCH models: Evidence from Egypt and Israel. Middle Eastern Finance and Economics, 2, 31-41. 
Franke, G. (1991). Exchange rate volatility and international trading strategy. Journal of International Money and Finance, 10(2), 292-307.

Gylfason, T., \& Radetzki, M. (1985). Does devaluation make sense in the least developed countries? (Seminar Paper No. 314). Stockholm: Institute of International Economic Studies.

Gylfason, T., \& Risager, O. (1984). Does devaluation improve the current account? European Economic Review, 25(1), 37-64.

Gylfason, T., \& Schmid, M. (1983). Does devaluation cause stagflation? Canadian Journal of Economics, 16(4), 641-654.

Hanson, J. A. (1983). Contractionary devaluation, substitution in production and consumption, and the role of the labor market. Journal of International Economics, 14, 179-189.

Hayakawa, K., \& Kimura, F. (2008). The effect of exchange rate volatility on international trade in East Asia (Discussion Paper No. 2008-03). Jakarta: Economic Research Institute for ASEAN and East Asia.

Hernández, L., \& Schmidt-Hebbel, K. (Eds.). (2002). Banking, financial integration, and international crises. Santiago: Central Bank of Chile.

Heston, A., Summers, R., \& Aten, B. (2002). Penn world table version 6.1. Philadelphia, PA: Center for International Comparisons at the University of Pennsylvania.

Hondroyiannis, G., Swamy, P. A. V. B., Tavlas, G., \& Ulan, M. (2005). Some further evidence on exchange-rate volatility and exports (Working Paper No. 28). Athens: Bank of Greece.

Irfan, M., Irfan, M., \& Awais, M. (2010). Modeling volatility of short-term interest rates by $\mathrm{ARCH}$ family models: Evidence from Pakistan and India. World Applied Sciences Journal, 9(10), 1089-2010.

Isard, P. (1995). Exchange rate economics. Cambridge, UK: Cambridge University Press.

Islam, S. (1984). Devaluation, stabilization policies, and the developing countries: A macroeconomic analysis. Journal of Development Economics, 14, 37-60. 
Jongwanich, J. (2010). Capital flows and real exchange rates in emerging Asian countries (Working Paper No. 210). Manila: Asian Development Bank.

Judson, R. A., \& Owen, A. L. (1996). Estimating dynamic panel data models: A practical guide for macroeconomists. Washington, DC: Federal Reserve Board of Governors.

Kemal, M. A. (2005). Exchange rate instability and trade: The case of Pakistan (Research Report No. 186). Islamabad: Pakistan Institute of Development Economics.

Kumar, R., \& Dhawan, R. (1991). Exchange rate volatility and Pakistan's exports to the developed world, 1974-1985. World Development, 19(9), 1225-1240.

McKenzie, M. D. (1999). The impact of exchange rate volatility on international trade flows. Journal of Economic Surveys, 13(1), 71-106.

Mustafa, K., \& Nishat, M. (2004). Volatility of exchange rate and export growth in Pakistan: The structure and interdependence in regional markets. Pakistan Development Review, 43(4), 813-828.

Ozturk, I. (2006). Exchange rate volatility and trade: A literature survey. International Journal of Applied Econometrics and Quantitative Studies, 3(1), 85-102.

Pattichis, C. (2003). Conditional exchange rate volatility, unit roots, and international trade. International Trade Journal, 17(1), 1-17.

Prasad, E., Rogoff, K., Wei, S.-J., \& Kose, M. A. (2004). Effects on financial globalization on developing countries: Some empirical evidence (Occasional Paper No. 220). Washington, DC: International Monetary Fund.

Qayyum, A., \& Kemal, A. R. (2006). Volatility spillover between the stock market and the foreign exchange market in Pakistan (Working Paper No. 2006-7). Islamabad: Pakistan Institute of Development Economics.

Quantitative Micro Software. (2007). EViews 6 user's guide II. Irvine, CA: Author. 
Rose, A. K. (2000). One money, one market: The effect of common currencies on trade. Economic Policy, 15(30), 7-46.

Sercu, P., \& Vanhulle, C. (1992). Exchange rate volatility, international trade and the value of exporting firms. Journal of Banking and Finance, 16(1), 155-182.

Siddiqui, M. A. (2009). Modeling Pak rupee volatility against five major currencies in the perspective of different exchange rate regimes. European Journal of Economics, Finance and Administrative Sciences, $17,81-96$.

Solimano, A. (1986). Contractionary devaluation in the Southern Cone: The case of Chile. Journal of Development Economics, 23, 135-151.

Tang, H. C. (2012). Why do imports fall more than exports especially during crises? Evidence from selected Asian economies (Working Paper on Regional Economic Integration No. 96). Manila: Asian Development Bank.

Tenreyro, S. (2007). On the trade impact of nominal exchange rate volatility. Journal of Development Economics, 82, 485-508.

van Wijnbergen, S. (1986). Exchange rate management and stabilization policies in developing countries. Journal of Development Economics, 23, 227-247. 


\section{Appendix}

\section{Comparative results for pooled series with three different unit root tests}

Table A1: Results based on panel unit root tests

\begin{tabular}{|c|c|c|c|c|c|c|}
\hline \multirow[t]{2}{*}{ Variable } & \multicolumn{2}{|c|}{$\begin{array}{c}\text { Levin, Lin, Chu (LLC) } \\
(2002) \\
\mathrm{H}_{0} \text { : Common unit roots } \\
\mathrm{H}_{\mathrm{a}} \text { : Stationarity }\end{array}$} & \multicolumn{2}{|c|}{$\begin{array}{c}\text { Im, Pesaran, Shin (IPS) } \\
\text { (2003) } \\
\mathrm{H}_{0}: \text { Individual unit } \\
\text { roots } \\
\mathrm{H}_{\mathrm{a}} \text { : Stationarity } \\
\end{array}$} & \multicolumn{2}{|c|}{$\begin{array}{c}\text { Hadri Lagrange } \\
\text { multiplier (HLM) (2000) } \\
\text { H}_{0:} \text { Stationarity } \\
\text { Ha: Unit root }_{\text {a }} \\
\text { (nonstationary) }\end{array}$} \\
\hline & Level & Difference & Level & Difference & Level & Difference \\
\hline $\mathrm{RX}$ & $7.95230^{\wedge}$ & $-77.3146^{*}$ & $7.90569^{\wedge}$ & $-44.9007^{*}$ & $69.1382^{\wedge}$ & $0.39975^{*}$ \\
\hline LNRX & $-5.64092^{*}$ & & & $-42.9672^{*}$ & & $-.42814^{*}$ \\
\hline DRX & $-68.5454^{*} \S$ & & $-44.9007^{*}$ & & $0.39975^{*}$ & \\
\hline $\mathrm{RM}$ & $7.74950^{\wedge}$ & $-32.4105^{*}$ & $7.63314^{\wedge}$ & $-51.9636^{*}$ & $65.8984^{\wedge}$ & $-0.37937^{*}$ \\
\hline LNRM & $-4.77200^{*}$ & & & $-58.3954^{*}$ & & $-1.30924^{*}$ \\
\hline DRM & $-15.3367^{*}$ & & $-51.9636^{*}$ & & $-0.37933^{*}$ & \\
\hline $\mathrm{TB}$ & $-4.6229^{*}$ & & $-10.8965^{*}$ & & $30.4937^{\wedge}$ & $-1.42482^{*}$ \\
\hline LNTB & $-6.81063^{*}$ & & $-14.1449^{*}$ & & & $-1.18560^{*}$ \\
\hline DTB & $-156.041^{*}$ & & $-126.591^{*}$ & & $-0.05601^{*}$ & \\
\hline $\mathrm{P}$ & $5.27950^{\wedge}$ & $-39.7603^{*}$ & $-6.0097^{\wedge}$ & $-41.8611^{*}$ & $26.7045^{\wedge}$ & $-2.70667^{*}$ \\
\hline LNP & $3.70968^{\wedge}$ & $-8.79989^{*}$ & $-4.10158^{*}$ & & $37.5834^{\wedge}$ & $-1.782^{*}$ \\
\hline $\mathrm{DP}$ & $-23.068^{*}$ & & $-41.8601^{*}$ & & $-2.70669^{*}$ & \\
\hline CPI & $3.23042^{\wedge}$ & $-39.7603^{*}$ & $12.5497^{\wedge}$ & $-35.2565^{*}$ & $79.1358^{\wedge}$ & $-0.53231^{*}$ \\
\hline LNCPI & $-17.1407^{*}$ & & $-6.14599 *$ & & & $-1.81521^{*}$ \\
\hline DCPI & $-41.3232^{*}$ & & $-38.7572^{*}$ & & & $-0.27555^{*}$ \\
\hline $\mathrm{MP}$ & $4.86390^{\wedge}$ & $-23.0747^{*}$ & $5.81468^{\wedge}$ & $-32.6942^{*}$ & $67.2631^{\wedge}$ & $-2.37179 *$ \\
\hline LNMP & $-4.01874^{*}$ & & & $-37.5175^{*}$ & & $-1.84560^{*}$ \\
\hline DMP & $-37.1732^{*} \S$ & & $-33.0737^{*}$ & & & $-2.38453^{*}$ \\
\hline RFR & $12.7778^{\wedge}$ & $72.3515^{*}$ & $11.9783^{\wedge}$ & $-37.7237^{*}$ & $25.8825^{\wedge}$ & $0.54973^{*}$ \\
\hline LNRFR & & $-109.346^{*}$ & & $-91.7945^{*}$ & & $-2.91806^{*}$ \\
\hline DRFR & $-34.9282 * \S$ & & $-37.7622^{*}$ & & $0.55064^{*}$ & \\
\hline $\mathrm{SP}$ & $4.59758^{\wedge}$ & $-89.2916^{*}$ & $5.4888^{\wedge}$ & $-75.2148^{*}$ & $55.4938^{\wedge}$ & $-0.65032^{*}$ \\
\hline LNSP & & $-90.7385^{*}$ & & $-80.1237^{*}$ & & $-0.47421^{*}$ \\
\hline DSP & $-84.6522^{*}$ & & $-75.6219^{*}$ & & $-0.80644^{*}$ & \\
\hline $\mathrm{RCF}$ & $0.19575^{\wedge}$ & $-94.0659^{*}$ & $-2.75244^{*}$ & & $41.7357^{\wedge}$ & $-0.14942^{*}$ \\
\hline DRCF & $-53.6034^{*}$ & & $-71.4790^{*}$ & & $-0.14974^{*}$ & \\
\hline RIR & $-3.1270^{*}$ & & $-13.0244^{*}$ & & $16.8158^{\wedge}$ & $-3.07201^{*}$ \\
\hline DRIR & -106.746 & & $-95.4949^{*}$ & & $-3.35617^{*}$ & \\
\hline RERD & $-2.81785^{*}$ & & $-3.19496^{*}$ & $-92.7994^{*}$ & $33.0965^{\wedge}$ & $-0.55557^{*}$ \\
\hline LNRERD & $-2.98556^{*}$ & & $-2.85995^{*}$ & & & $0.33884^{*}$ \\
\hline VOLG & $-16.3071^{*}$ & & $-36.1049 *$ & $-95.445^{*}$ & $4.87767^{\wedge}$ & $-0.93286^{*}$ \\
\hline LNVOLG & $-18.0385^{*}$ & & $-30.3495^{*}$ & & & $-0.64995^{*}$ \\
\hline VOLE & $-40.4186^{*}$ & & $-57.5758^{*}$ & $-160.639 *$ & $10.0507^{\wedge}$ & $-0.76542^{*}$ \\
\hline LNVOLE & $-41.8546^{*}$ & & $-54.4244^{*}$ & & & $-1.68881^{*}$ \\
\hline
\end{tabular}




\begin{tabular}{|c|c|c|c|c|c|c|}
\hline \multirow[t]{2}{*}{ Variable } & \multicolumn{2}{|c|}{$\begin{array}{l}\text { Levin, Lin, Chu (LLC) } \\
(2002) \\
H_{0} \text { : Common unit roots } \\
\text { Ha: Stationarity }\end{array}$} & \multicolumn{2}{|c|}{$\begin{array}{c}\text { Im, Pesaran, Shin (IPS) } \\
\text { (2003) } \\
\mathrm{H}_{0} \text { : Individual unit } \\
\text { roots } \\
\mathrm{H}_{\mathrm{a}} \text { : Stationarity }\end{array}$} & \multicolumn{2}{|c|}{$\begin{array}{c}\text { Hadri Lagrange } \\
\text { multiplier (HLM) (2000) } \\
\text { Ho: Stationarity } \\
\mathrm{H}_{\mathrm{a}} \text { : Unit root } \\
\text { (nonstationary) }\end{array}$} \\
\hline & Level & Difference & Level & Difference & Level & Difference \\
\hline VOLP & $-9.31378^{*}$ & & $-26.8833^{*}$ & $-128.434^{*}$ & $-7.90614^{\wedge}$ & $-2.23928^{*}$ \\
\hline LNVOLP & $-14.2295^{*}$ & & $-29.4042^{*}$ & & & $0.62023^{*}$ \\
\hline VOLT & $-24.0896^{*}$ & & $-41.9023^{*}$ & $-110.135^{*}$ & $7.59183^{\wedge}$ & $0.42357^{*}$ \\
\hline LNVOLT & $-23.4530^{*}$ & & $-36.3405^{*}$ & & & $"-0.39917^{*}$ \\
\hline VOLC & $-25.0956^{*}$ & & $-29.1406^{*}$ & $-115.693^{*}$ & $6.98159^{\wedge}$ & $0.35744^{*}$ \\
\hline LNVOLC & $-11.4583^{*}$ & & -15.9807 & & & $0.71311^{*}$ \\
\hline RERR & $-7.51395^{*}$ & & $-8.28275^{*}$ & & $49.5481^{\wedge}$ & $-1.9174^{*}$ \\
\hline LNRERR & $-4.46648^{*}$ & & $-4.70145^{*}$ & & & $-2.40685^{*}$ \\
\hline VOLGR & $-34.7379 *$ & & $-64.3387^{*}$ & & $5.00038^{\wedge}$ & $1.96043^{\wedge}$ \\
\hline LNVOLGR & $-15.0746^{*}$ & & $-38.9511^{*}$ & & & $-0.35630^{*}$ \\
\hline VOLER & $-21.3477^{*}$ & & $-56.6643^{*}$ & & $7.15261^{\wedge}$ & $-0.23498^{*}$ \\
\hline LNVOLER & $-19.4552^{*}$ & & $-53.0982^{*}$ & & & $-1.54498^{*}$ \\
\hline VOLPR & $-35.4050^{*}$ & & $-48.7782^{*}$ & & $5.18746^{\wedge}$ & $-2.00689^{*}$ \\
\hline LNVOLPR & $-30.8714^{*}$ & & $-55.2507^{*}$ & & & $-0.60690^{*}$ \\
\hline VOLTR & $-33.8811^{*}$ & & $-45.8619^{*}$ & & $1.48524^{\wedge}$ & $-2.65418^{*}$ \\
\hline LNVOLTR & -20.0706 & & $-39.6877^{*}$ & & & $-1.95911^{*}$ \\
\hline VOLCR & $-24.7446^{*}$ & & $-27.5626^{*}$ & $-64.2608^{*}$ & $5.0314^{\wedge}$ & $-0.88942^{*}$ \\
\hline LNVOLCR & $-10.2033^{*}$ & & $-16.7669^{*}$ & & & $-0.26952^{*}$ \\
\hline FRFGIRDF & $-11.2279 *$ & & $-22.2389^{*}$ & & $12.6420^{\wedge}$ & $-2.23543^{*}$ \\
\hline GDMGIRDF & $-3.61924^{*}$ & & $-12.1150^{*}$ & & $14.7927^{\wedge}$ & $-2.3137^{*}$ \\
\hline NLGGIRDF & $-3.31749^{*}$ & & $-14.4048^{*}$ & & $-14.7948^{\wedge}$ & $-2.02165^{*}$ \\
\hline JPYGIRDF & $-4.03637^{*}$ & & $-15.6493^{*}$ & & $13.3510^{\wedge}$ & $-1.9992^{*}$ \\
\hline UKPGIRDF & $-4.24617^{*}$ & & $-18.3488^{*}$ & & $13.1149^{\wedge}$ & $-2.02780^{*}$ \\
\hline USDGIRDF & $-5.92308^{*}$ & & $-16.5827^{*}$ & & $16.368^{\wedge}$ & $-3.72168^{*}$ \\
\hline
\end{tabular}

Note: Stationarity established at ${ }^{*}=1 \%$ level of significance. ${ }^{n}=$ second difference, $\S=$ without exogenous variable (neither intercept nor trend), $\wedge$ = unit root (nonstationary) series. 


\section{Estimation results of exchange rate volatility impact on trade}

Table B1: Exchange rate volatility in real exports equations: Full sample

\begin{tabular}{|c|c|c|c|c|}
\hline & \multicolumn{2}{|c|}{ FULL SAMPLE - USD } & \multicolumn{2}{|c|}{ FULL SAMPLE - PKR } \\
\hline $\begin{array}{l}\text { REAL EXPORT } \\
\text { FUNCTIONS }\end{array}$ & $\begin{array}{c}(1) \\
\text { Double } \\
\log \\
\end{array}$ & $\begin{array}{c}\text { (2) } \\
\text { First } \\
\text { difference }\end{array}$ & $\begin{array}{c}(3) \\
\text { Double } \\
\log \\
\end{array}$ & $\begin{array}{c}(4) \\
\text { First } \\
\text { difference } \\
\end{array}$ \\
\hline Rate of inflation & $\begin{array}{r}-0.003752 \\
(-2.06)^{*}\end{array}$ & $\begin{array}{r}0.070022 \\
(1.05)\end{array}$ & $\begin{array}{r}0.002077 \\
(1.15)\end{array}$ & \\
\hline $\begin{array}{l}\text { Nontradable commodity } \\
\text { prices }\end{array}$ & $\begin{array}{r}0.006851 \\
(1.79)^{* *}\end{array}$ & $\begin{array}{r}0.430305 \\
(2.81)^{*}\end{array}$ & & $\begin{array}{r}0.507029 \\
(3.93)^{*}\end{array}$ \\
\hline Production index & $\begin{array}{r}0.252128 \\
(35.94)^{*}\end{array}$ & $\begin{array}{r}0.860931 \\
(54.92)^{*}\end{array}$ & $\begin{array}{r}0.150485 \\
(30.75)^{*}\end{array}$ & $\begin{array}{r}0.798954 \\
(55.85)^{*}\end{array}$ \\
\hline Real foreign reserves & $\begin{array}{r}-0.005978 \\
(-5.02)^{*}\end{array}$ & $\begin{array}{r}-3.10 \mathrm{E}-06 \\
(-2.52)^{*}\end{array}$ & $\begin{array}{r}-0.005266 \\
(-4.50)^{*}\end{array}$ & $\begin{array}{r}-4.37 \mathrm{E}-06 \\
(-3.61)^{*}\end{array}$ \\
\hline Real interest rate & $\begin{array}{r}-0.002768 \\
(-5.05)^{*}\end{array}$ & $\begin{array}{r}0.00516 \\
(0.59)\end{array}$ & $\begin{array}{r}-0.001744 \\
(-3.21)^{*}\end{array}$ & $\begin{array}{r}-0.001399 \\
(-0.18)\end{array}$ \\
\hline Real capital flows & & & $\begin{array}{r}0.003038 \\
(5.07)^{*}\end{array}$ & $\begin{array}{r}0.450711 \\
(41.67)^{*}\end{array}$ \\
\hline Real exchange rate & $\begin{array}{r}-0.181819 \\
(-20.33)^{*}\end{array}$ & $\begin{array}{r}-0.00194 \\
(-1.14)\end{array}$ & $\begin{array}{r}-0.081019 \\
(-12.12)^{*}\end{array}$ & $\begin{array}{r}-0.204441 \\
(-2.16)^{*}\end{array}$ \\
\hline GARCH volatility & $\begin{array}{r}0.003943 \\
(0.86)\end{array}$ & $\begin{array}{r}2.20 \mathrm{E}-05 \\
(2.79)^{*}\end{array}$ & $\begin{array}{r}-0.004545 \\
(-2.36)^{*}\end{array}$ & $\begin{array}{r}0.06914 \\
(2.15)^{*}\end{array}$ \\
\hline EGARCH volatility & $\begin{array}{r}0.012818 \\
(3.62)^{*}\end{array}$ & $\begin{array}{r}1.98 \mathrm{E}-05 \\
(1.96)^{*}\end{array}$ & $\begin{array}{r}0.000264 \\
(0.14)\end{array}$ & $\begin{array}{r}6.15 \mathrm{E}-07 \\
(1.11)\end{array}$ \\
\hline TGARCH volatility & $\begin{array}{r}-0.008792 \\
(-2.76)^{*}\end{array}$ & $\begin{array}{r}-7.62 \mathrm{E}-06 \\
(-2.39)^{*}\end{array}$ & $\begin{array}{r}0.004521 \\
(1.70)^{* *}\end{array}$ & $\begin{array}{r}-0.07016 \\
(-2.18)^{*}\end{array}$ \\
\hline CGARCH volatility & $\begin{array}{r}-0.008211 \\
(-2.82)^{*}\end{array}$ & $\begin{array}{r}-9.18 \mathrm{E}-05 \\
(-2.84)^{*}\end{array}$ & $\begin{array}{r}-0.006369 \\
(-3.26)^{*}\end{array}$ & $\begin{array}{r}-0.117068 \\
(-1.67)^{* *}\end{array}$ \\
\hline Power GARCH volatility & $\begin{array}{r}0.012247 \\
(2.72)^{*}\end{array}$ & $\begin{array}{r}2.70 \mathrm{E}-05 \\
(2.68)^{*}\end{array}$ & $\begin{array}{r}0.002146 \\
(0.81)\end{array}$ & $\begin{array}{r}0.084626 \\
(1.78)^{* *}\end{array}$ \\
\hline Shares price index & $\begin{array}{r}0.025674 \\
(9.25)^{*}\end{array}$ & $\begin{array}{r}0.051527 \\
(3.17)^{*}\end{array}$ & & \\
\hline Common constant & $\begin{array}{r}0.268236 \\
(10.56)^{*}\end{array}$ & $\begin{array}{r}0.554318 \\
(5.96)^{*}\end{array}$ & $\begin{array}{r}-0.089916 \\
(-4.73)^{*}\end{array}$ & $\begin{array}{r}0.490587 \\
(6.15)^{*}\end{array}$ \\
\hline $\begin{array}{l}1 \text { st lagged real exports } \\
\text { (SPEED OF } \\
\text { ADJUSTMENT) }\end{array}$ & $\begin{array}{l}0.763409 \\
(130.61)^{*}\end{array}$ & $\begin{array}{r}-0.256648 \\
(-26.33)^{*}\end{array}$ & $\begin{array}{l}0.832503 \\
(170.24)^{*}\end{array}$ & $\begin{array}{r}-0.214491 \\
(-24.29)\end{array}$ \\
\hline Adjusted $\mathrm{R}^{2}$ & 0.992480 & 0.320821 & 0.993171 & 0.430063 \\
\hline DW statistics & 2.362268 & 2.320321 & 2.482831 & 2.342896 \\
\hline
\end{tabular}

Note: Significant at $* 5$ and $* * 10 \%$, respectively. 
Table B2: Exchange rate volatility in real exports equations: Developing countries sub-sample

[Pooled EGLS (cross-section weights) fixed-effects estimation]

\begin{tabular}{|c|c|c|c|c|c|c|}
\hline & \multicolumn{3}{|c|}{ LDC - SUB-SAMPLE - USD } & \multicolumn{3}{|c|}{ LDC - SUB-SAMPLE - PKR } \\
\hline & $\begin{array}{c}\text { Unit } \\
\text { change }\end{array}$ & Elasticity & $\begin{array}{c}\text { Growth } \\
\text { rate }\end{array}$ & $\begin{array}{c}\text { Unit } \\
\text { change }\end{array}$ & Elasticity & $\begin{array}{c}\text { Growth } \\
\text { rate }\end{array}$ \\
\hline REAL EXPORT & $(1)$ & $(2)$ & (3) & $(4)$ & (5) & (6) \\
\hline FUNCTIONS & Level & Double log & $\begin{array}{c}\text { First } \\
\text { difference }\end{array}$ & Level & Double log & $\begin{array}{c}\text { First } \\
\text { difference }\end{array}$ \\
\hline Rate of inflation & $\begin{array}{r}-0.03194 \\
(-3.89)^{*}\end{array}$ & $\begin{array}{r}-0.010254 \\
(-3.27)^{*}\end{array}$ & & $\begin{array}{r}-0.032332 \\
(-3.94)^{*}\end{array}$ & $\begin{array}{r}-0.00669 \\
(-2.07)^{*}\end{array}$ & $\begin{array}{r}0.094601 \\
(2.04)^{*}\end{array}$ \\
\hline $\begin{array}{l}\text { Nontradable } \\
\text { commodity } \\
\text { prices }\end{array}$ & $\begin{array}{r}-0.009083 \\
(-2.84)^{*}\end{array}$ & $\begin{array}{r}-0.025432 \\
(-4.33)^{*}\end{array}$ & & $\begin{array}{r}-0.009171 \\
(-2.87)^{*}\end{array}$ & $\begin{array}{r}-0.02136 \\
(-3.76)^{*}\end{array}$ & $\begin{array}{r}0.244857 \\
(3.46)^{*}\end{array}$ \\
\hline $\begin{array}{l}\text { Production } \\
\text { index }\end{array}$ & $\begin{array}{r}0.008733 \\
(3.56)^{*}\end{array}$ & $\begin{array}{r}0.136881 \\
(14.66)^{*}\end{array}$ & $\begin{array}{l}0.22105 \\
(22.03)^{*}\end{array}$ & $\begin{array}{r}0.008721 \\
(3.55)^{*}\end{array}$ & $\begin{array}{l}0.11774 \\
(13.78)^{*}\end{array}$ & $\begin{array}{l}0.22412 \\
(22.12)^{*}\end{array}$ \\
\hline $\begin{array}{l}\text { Real foreign } \\
\text { reserves }\end{array}$ & $\begin{array}{r}-6.57 \mathrm{E}-06 \\
(-4.10)^{*}\end{array}$ & $\begin{array}{r}-0.004166 \\
(-1.44)\end{array}$ & $\begin{array}{r}-4.90 \mathrm{E}-06 \\
(-3.27)^{*}\end{array}$ & $\begin{array}{r}-6.57 \mathrm{E}-06 \\
(-4.10)^{*}\end{array}$ & $\begin{array}{r}-0.00702 \\
(-2.57)^{*}\end{array}$ & $\begin{array}{r}-4.90 \mathrm{E}-06 \\
(-3.27)^{*}\end{array}$ \\
\hline $\begin{array}{l}\text { Real interest } \\
\text { rate }\end{array}$ & $\begin{array}{r}-0.001129 \\
(-0.15)\end{array}$ & $\begin{array}{r}-0.001754 \\
(-1.83)^{* *}\end{array}$ & $\begin{array}{r}0.004019 \\
(0.45)\end{array}$ & $\begin{array}{r}-0.000981 \\
(-0.13)\end{array}$ & $\begin{array}{r}-0.001351 \\
(-1.41)\end{array}$ & $\begin{array}{r}0.003962 \\
(0.45)\end{array}$ \\
\hline $\begin{array}{l}\text { Real capital } \\
\text { flows }\end{array}$ & $\begin{array}{r}0.047874 \\
(5.63)^{*}\end{array}$ & $\begin{array}{r}0.002659 \\
(2.44)^{*}\end{array}$ & $\begin{array}{r}0.241026 \\
(16.20)^{*}\end{array}$ & $\begin{array}{r}0.048119 \\
(5.66)^{*}\end{array}$ & $\begin{array}{r}0.003095 \\
(2.84)^{*}\end{array}$ & $\begin{array}{r}0.240633 \\
(16.16)^{*}\end{array}$ \\
\hline $\begin{array}{l}\text { Real exchange } \\
\text { rate }\end{array}$ & $\begin{array}{r}-1.34 \mathrm{E}-05 \\
(-0.04)\end{array}$ & $\begin{array}{r}-0.06461 \\
(-4.93)^{*}\end{array}$ & $\begin{array}{r}-0.000526 \\
(-0.52)\end{array}$ & $\begin{array}{r}-0.014894 \\
(-0.44)\end{array}$ & $\begin{array}{r}-0.033189 \\
(-2.01)^{*}\end{array}$ & $\begin{array}{r}-0.029644 \\
(-0.46)\end{array}$ \\
\hline $\begin{array}{l}\text { GARCH } \\
\text { volatility }\end{array}$ & $\begin{array}{r}9.42 \mathrm{E}-07 \\
(1.37)\end{array}$ & $\begin{array}{r}0.001599 \\
(0.30)\end{array}$ & $\begin{array}{r}-9.02 \mathrm{E}-06 \\
(-1.94)^{*}\end{array}$ & $\begin{array}{r}-0.002274 \\
(-0.49)\end{array}$ & $\begin{array}{r}-0.003001 \\
(-0.67)\end{array}$ & $\begin{array}{r}0.029511 \\
(1.33)\end{array}$ \\
\hline $\begin{array}{l}\text { EGARCH } \\
\text { volatility }\end{array}$ & $\begin{array}{r}-8.40 \mathrm{E}-06 \\
(-1.48)\end{array}$ & $\begin{array}{r}0.008615 \\
(2.17)^{*}\end{array}$ & $\begin{array}{r}-1.56 \mathrm{E}-05 \\
(-2.58)^{*}\end{array}$ & $\begin{array}{r}-5.11 \mathrm{E}-07 \\
(-0.68)\end{array}$ & $\begin{array}{r}-0.000841 \\
(-0.27)\end{array}$ & $\begin{array}{r}1.57 \mathrm{E}-07 \\
(0.33)\end{array}$ \\
\hline $\begin{array}{l}\text { TGARCH } \\
\text { volatility }\end{array}$ & $\begin{array}{r}4.08 \mathrm{E}-07 \\
(1.13)\end{array}$ & $\begin{array}{r}-0.008893 \\
(-2.44)^{*}\end{array}$ & $\begin{array}{r}-2.33 \mathrm{E}-07 \\
(-0.12)\end{array}$ & $\begin{array}{r}0.002809 \\
(0.12)\end{array}$ & $\begin{array}{r}0.002284 \\
(0.45)\end{array}$ & $\begin{array}{r}-0.010532 \\
(-0.47)\end{array}$ \\
\hline $\begin{array}{l}\text { CGARCH } \\
\text { volatility }\end{array}$ & $\begin{array}{r}4.28 \mathrm{E}-07 \\
(0.38)\end{array}$ & $\begin{array}{r}-0.005963 \\
(-1.57)\end{array}$ & $\begin{array}{r}3.96 \mathrm{E}-05 \\
(2.07)^{*}\end{array}$ & $\begin{array}{r}-0.005263 \\
(-0.27)\end{array}$ & $\begin{array}{r}0.00153 \\
(0.37)\end{array}$ & $\begin{array}{r}-0.065795 \\
(-1.37)\end{array}$ \\
\hline $\begin{array}{l}\text { Power GARCH } \\
\text { volatility }\end{array}$ & $\begin{array}{r}-6.35 \mathrm{E}-09 \\
(-0.15)\end{array}$ & $\begin{array}{r}0.013315 \\
(2.67)^{*}\end{array}$ & $\begin{array}{r}-4.41 \mathrm{E}-06 \\
(-0.74)\end{array}$ & $\begin{array}{r}0.006108 \\
(0.34)\end{array}$ & $\begin{array}{r}0.00623 \\
(1.20)\end{array}$ & $\begin{array}{r}-0.002186 \\
(-0.07)\end{array}$ \\
\hline $\begin{array}{l}\text { Shares price } \\
\text { index }\end{array}$ & $\begin{array}{l}0.0129 \\
(6.90)^{*}\end{array}$ & $\begin{array}{r}0.039854 \\
(7.90)^{*}\end{array}$ & $\begin{array}{r}0.016558 \\
(1.56)\end{array}$ & $\begin{array}{r}0.012979 \\
(6.97)^{*}\end{array}$ & $\begin{array}{l}0.0366 \\
(7.54)^{*}\end{array}$ & $\begin{array}{r}0.017835 \\
(1.67)^{* *}\end{array}$ \\
\hline $\begin{array}{l}\text { Common } \\
\text { constant }\end{array}$ & $\begin{array}{r}2.160674 \\
(5.63)^{*}\end{array}$ & $\begin{array}{r}0.218122 \\
(5.78)^{*}\end{array}$ & $\begin{array}{r}0.610631 \\
(9.45)^{*}\end{array}$ & $\begin{array}{r}2.216188 \\
(5.46)^{*}\end{array}$ & $\begin{array}{r}0.080553 \\
(2.37)^{*}\end{array}$ & $\begin{array}{r}0.601433 \\
(9.26)^{*}\end{array}$ \\
\hline $\begin{array}{l}1^{\text {st }} \text { lagged real } \\
\text { exports }\end{array}$ & $\begin{array}{l}0.972748 \\
(210.09)^{*}\end{array}$ & $\begin{array}{r}0.832916 \\
(92.64)^{*}\end{array}$ & $\begin{array}{r}-0.301646 \\
(-17.65)^{*}\end{array}$ & $\begin{array}{l}0.972815 \\
(210.33)^{*}\end{array}$ & $\begin{array}{r}0.845077 \\
(97.13)^{*}\end{array}$ & $\begin{array}{r}-0.301887 \\
(-17.66)^{*}\end{array}$ \\
\hline $\begin{array}{l}1^{\text {st }} \text { lag of } \\
\text { inflation rate }\end{array}$ & & & $\begin{array}{r}0.107645 \\
(2.32)^{*}\end{array}$ & & & \\
\hline $\begin{array}{l}2^{\text {nd }} \text { lag of } \\
\text { tradable } \\
\text { commodity } \\
\text { prices }\end{array}$ & & & $\begin{array}{r}0.230301 \\
(3.29)^{*}\end{array}$ & & & \\
\hline Adjusted $\mathrm{R}^{2}$ & 0.985346 & 0.989761 & 0.285506 & 0.985334 & 0.989712 & 0.284935 \\
\hline DW statistics & 2.712008 & 2.566917 & 2.140201 & 2.711772 & 2.587099 & 2.140844 \\
\hline
\end{tabular}

Note: Significant at $* 5 \%$ and $* * 10 \%$, respectively. 
Table B3: Exchange rate volatility in real imports equations: Full sample

[Pooled EGLS (cross-section weights) fixed-effects estimation]

\begin{tabular}{|c|c|c|c|c|}
\hline & \multicolumn{2}{|c|}{ FULL SAMPLE - USD } & \multicolumn{2}{|c|}{ FULL SAMPLE - PKR } \\
\hline $\begin{array}{l}\text { REAL IMPORT } \\
\text { FUNCTIONS }\end{array}$ & $\begin{array}{c}(1) \\
\text { Double } \\
\log \end{array}$ & $\begin{array}{c}\text { (2) } \\
\text { First } \\
\text { difference }\end{array}$ & $\begin{array}{c}(4) \\
\text { Double } \\
\text { log }\end{array}$ & $\begin{array}{c}\text { (5) } \\
\text { First } \\
\text { difference }\end{array}$ \\
\hline Rate of inflation & $\begin{array}{r}0.005565 \\
(3.07)^{*}\end{array}$ & & $\begin{array}{r}0.009225 \\
(4.90)^{*}\end{array}$ & \\
\hline $\begin{array}{l}\text { Nontradable commodity } \\
\text { prices }\end{array}$ & $\begin{array}{r}0.010833 \\
(2.75)^{*}\end{array}$ & $\begin{array}{r}0.608685 \\
(3.98)^{*}\end{array}$ & $\begin{array}{r}0.013983 \\
(3.63)^{*}\end{array}$ & $\begin{array}{r}0.454847 \\
(2.90)^{*}\end{array}$ \\
\hline Production index & $\begin{array}{l}0.19767 \\
(31.92)^{*}\end{array}$ & $\begin{array}{r}0.882021 \\
(53.93)^{*}\end{array}$ & $\begin{array}{r}0.150482 \\
(26.95)^{*}\end{array}$ & $\begin{array}{r}0.879239 \\
(53.88)^{*}\end{array}$ \\
\hline Real foreign reserves & $\begin{array}{r}-0.003457 \\
(-2.94)^{*}\end{array}$ & $\begin{array}{r}-2.81 \mathrm{E}-06 \\
(-2.29)^{*}\end{array}$ & $\begin{array}{r}-0.009054 \\
(-7.60)^{*}\end{array}$ & $\begin{array}{r}-2.86 \mathrm{E}-06 \\
(-2.33)^{*}\end{array}$ \\
\hline Real interest rate & $\begin{array}{r}-0.002308 \\
(-4.36)^{*}\end{array}$ & $\begin{array}{r}0.005502 \\
(0.61)\end{array}$ & $\begin{array}{r}-0.002043 \\
(-3.84)^{*}\end{array}$ & $\begin{array}{r}0.003737 \\
(0.41)\end{array}$ \\
\hline Real capital flows & $\begin{array}{r}0.007009 \\
(11.94)^{*}\end{array}$ & $\begin{array}{r}-0.419409 \\
(-37.84)^{*}\end{array}$ & $\begin{array}{r}0.006231 \\
(10.43)^{*}\end{array}$ & $\begin{array}{r}-0.420927 \\
(-38.02)^{*}\end{array}$ \\
\hline Real exchange rate & $\begin{array}{r}-0.164068 \\
(-19.49)^{*}\end{array}$ & $\begin{array}{r}-0.003114 \\
(-1.82)^{* *}\end{array}$ & $\begin{array}{r}-0.06582 \\
(-9.63)^{*}\end{array}$ & $\begin{array}{r}-0.234609 \\
(-2.40)^{*}\end{array}$ \\
\hline GARCH volatility & $\begin{array}{r}-0.01071 \\
(-2.28)^{*}\end{array}$ & $\begin{array}{r}2.19 \mathrm{E}-05 \\
(2.91)^{*}\end{array}$ & $\begin{array}{r}-0.004463 \\
(-2.26)^{*}\end{array}$ & $\begin{array}{r}0.083016 \\
(2.50)^{*}\end{array}$ \\
\hline EGARCH volatility & $\begin{array}{r}0.011266 \\
(2.88)^{*}\end{array}$ & $\begin{array}{r}1.37 \mathrm{E}-05 \\
(1.39)\end{array}$ & $\begin{array}{r}0.004092 \\
(2.18)^{*}\end{array}$ & $\begin{array}{r}5.83 \mathrm{E}-07 \\
(0.96)\end{array}$ \\
\hline TGARCH volatility & $\begin{array}{l}-0.00525 \\
(-1.62)^{* *}\end{array}$ & $\begin{array}{r}-1.03 \mathrm{E}-05 \\
(-3.24)^{*}\end{array}$ & $\begin{array}{r}0.001409 \\
(0.52)\end{array}$ & $\begin{array}{r}-0.083946 \\
(-2.51)^{*}\end{array}$ \\
\hline CGARCH volatility & $\begin{array}{r}-0.002904 \\
(-1.00)\end{array}$ & $\begin{array}{r}-9.01 \mathrm{E}-05 \\
(-2.92)^{*}\end{array}$ & $\begin{array}{r}-0.006873 \\
(-3.43)^{*}\end{array}$ & $\begin{array}{r}-0.138623 \\
(-1.93)^{*}\end{array}$ \\
\hline Power GARCH volatility & $\begin{array}{r}0.008457 \\
(1.80)^{* *}\end{array}$ & $\begin{array}{r}3.30 \mathrm{E}-05 \\
(3.36)^{*}\end{array}$ & $\begin{array}{r}-0.001041 \\
(-0.37)\end{array}$ & $\begin{array}{r}0.098035 \\
(1.98)^{*}\end{array}$ \\
\hline Shares price index & $\begin{array}{r}0.026323 \\
(9.47)^{*}\end{array}$ & $\begin{array}{r}0.060489 \\
(3.56)^{*}\end{array}$ & $\begin{array}{r}0.012248 \\
(4.28)^{*}\end{array}$ & $\begin{array}{r}0.005675 \\
(3.25)^{*}\end{array}$ \\
\hline Common constant & $\begin{array}{r}0.259832 \\
(10.26)^{*}\end{array}$ & $\begin{array}{r}0.497037 \\
(5.29)^{*}\end{array}$ & $\begin{array}{r}-0.095355 \\
(-4.06)^{*}\end{array}$ & $\begin{array}{r}0.208188 \\
(1.55)\end{array}$ \\
\hline $1^{\text {st }}$ lagged real imports & $\begin{array}{l}0.783819 \\
(141.30)^{*}\end{array}$ & $\begin{array}{l}-0.22437 \\
(-24.66)^{*}\end{array}$ & $\begin{array}{l}0.817296 \\
(155.86)^{*}\end{array}$ & $\begin{array}{r}-0.224069 \\
(-24.66)^{*}\end{array}$ \\
\hline $1^{\text {st }}$ lag of inflation rate & & $\begin{array}{r}0.101585 \\
(1.60)^{* *}\end{array}$ & & $\begin{array}{r}0.100752 \\
(1.61)^{* *}\end{array}$ \\
\hline Weighted adjusted $\mathrm{R}^{2}$ & 0.991765 & 0.388641 & 0.991577 & 0.388936 \\
\hline Weighted DW statistics & 2.464956 & 2.314511 & 2.520785 & 2.311633 \\
\hline
\end{tabular}

Note: Significant at $* 5 \%$ and $* * 10 \%$, respectively. 


\section{Table B4: Exchange rate volatility in real imports equations: Developing countries sub-sample}

[Pooled EGLS (cross-section weights) fixed-effects estimation]

\begin{tabular}{|c|c|c|c|c|c|c|}
\hline & \multicolumn{3}{|c|}{ LDC - SUB-SAMPLE - USD } & \multicolumn{3}{|c|}{ LDC - SUB-SAMPLE - PKR } \\
\hline & (1) & (2) & (3) & (4) & (5) & (6) \\
\hline $\begin{array}{l}\text { REAL IMPORT } \\
\text { FUNCTIONS }\end{array}$ & Level & $\begin{array}{l}\text { Double } \\
\log \end{array}$ & $\begin{array}{c}\text { First } \\
\text { difference }\end{array}$ & Level & $\begin{array}{c}\text { Double } \\
\log \end{array}$ & $\begin{array}{c}\text { First } \\
\text { difference }\end{array}$ \\
\hline Rate of inflation & $\begin{array}{r}-0.034172 \\
(-3.27)^{*}\end{array}$ & & & $\begin{array}{r}-0.034475 \\
(-3.30)^{*}\end{array}$ & $\begin{array}{r}0.000397 \\
(0.11)\end{array}$ & \\
\hline $\begin{array}{l}\text { Nontradable } \\
\text { commodity prices }\end{array}$ & $\begin{array}{r}-0.015058 \\
(-3.98)^{*}\end{array}$ & $\begin{array}{r}-0.036173 \\
(-5.47)^{*}\end{array}$ & $\begin{array}{r}0.044009 \\
(0.63)\end{array}$ & $\begin{array}{r}-0.015088 \\
(-4.00)^{*}\end{array}$ & $\begin{array}{r}-0.03177 \\
(-4.98)^{*}\end{array}$ & $\begin{array}{r}0.039217 \\
(0.56)\end{array}$ \\
\hline Production index & $\begin{array}{r}0.011494 \\
(4.46)^{*}\end{array}$ & $\begin{array}{r}0.152506 \\
(14.31)^{*}\end{array}$ & $\begin{array}{r}0.220168 \\
(22.05)^{*}\end{array}$ & $\begin{array}{r}0.011362 \\
(4.42)^{*}\end{array}$ & $\begin{array}{r}0.104788 \\
(11.88)^{*}\end{array}$ & $\begin{array}{r}0.222932 \\
(22.12)^{*}\end{array}$ \\
\hline $\begin{array}{l}\text { Real foreign } \\
\text { reserves }\end{array}$ & $\begin{array}{r}-1.30 \mathrm{E}-05 \\
(-6.67)^{*}\end{array}$ & & $\begin{array}{r}-3.33 \mathrm{E}-06 \\
(-2.19)^{*}\end{array}$ & $\begin{array}{r}-1.30 \mathrm{E}-05 \\
(-6.68)^{*}\end{array}$ & $\begin{array}{r}-0.005814 \\
(-1.89)^{* *}\end{array}$ & $\begin{array}{r}-3.32 \mathrm{E}-06 \\
(-2.18)^{*}\end{array}$ \\
\hline Real interest rate & $\begin{array}{r}-0.025685 \\
(-2.59)^{*}\end{array}$ & $\begin{array}{r}-0.002909 \\
(-2.74)^{*}\end{array}$ & $\begin{array}{r}0.010577 \\
(1.07)\end{array}$ & $\begin{array}{r}-0.025654 \\
(-2.59)^{*}\end{array}$ & $\begin{array}{r}-0.002501 \\
(-2.34)^{*}\end{array}$ & $\begin{array}{r}0.010436 \\
(1.06)\end{array}$ \\
\hline Real capital flows & $\begin{array}{r}-0.112213 \\
(-10.03)^{*}\end{array}$ & $\begin{array}{r}0.008712 \\
(7.14)^{*}\end{array}$ & $\begin{array}{r}-0.656933 \\
(-42.01)^{*}\end{array}$ & $\begin{array}{l}-0.11193 \\
(-10.01)^{*}\end{array}$ & $\begin{array}{r}0.009613 \\
(7.93)^{*}\end{array}$ & $\begin{array}{r}-0.657638 \\
(-41.96)^{*}\end{array}$ \\
\hline Real exchange rate & $\begin{array}{r}-0.000172 \\
(-0.38)\end{array}$ & $\begin{array}{r}-0.145409 \\
(-9.11)^{*}\end{array}$ & $\begin{array}{r}-0.000586 \\
(-0.59)\end{array}$ & $\begin{array}{r}-0.021821 \\
(-0.50)\end{array}$ & $\begin{array}{r}-0.103391 \\
(-5.51)^{*}\end{array}$ & $\begin{array}{r}-0.037981 \\
(-0.59)\end{array}$ \\
\hline GARCH volatility & $\begin{array}{r}4.71 \mathrm{E}-07 \\
(0.52)\end{array}$ & $\begin{array}{r}-0.012183 \\
(-1.94)^{*}\end{array}$ & $\begin{array}{r}-1.13 \mathrm{E}-05 \\
(-2.52)^{*}\end{array}$ & $\begin{array}{r}-0.000853 \\
(-0.14)\end{array}$ & $\begin{array}{r}-0.001041 \\
(-0.20)\end{array}$ & $\begin{array}{r}0.036114 \\
(1.65)^{* *}\end{array}$ \\
\hline $\begin{array}{l}\text { EGARCH } \\
\text { volatility }\end{array}$ & $\begin{array}{r}-5.68 \mathrm{E}-06 \\
(-0.77)\end{array}$ & $\begin{array}{r}0.009577 \\
(1.99)^{*}\end{array}$ & $\begin{array}{r}-2.03 \mathrm{E}-05 \\
(-3.49)^{*}\end{array}$ & $\begin{array}{r}4.14 \mathrm{E}-09 \\
(0.00)\end{array}$ & $\begin{array}{r}0.002632 \\
(0.78)\end{array}$ & $\begin{array}{r}4.88 \mathrm{E}-08 \\
(0.10)\end{array}$ \\
\hline $\begin{array}{l}\text { TGARCH } \\
\text { volatility }\end{array}$ & $\begin{array}{r}5.07 \mathrm{E}-07 \\
(1.07)\end{array}$ & $\begin{array}{r}-0.006813 \\
(-1.75)^{* *}\end{array}$ & $\begin{array}{r}-6.28 \mathrm{E}-07 \\
(-0.34)\end{array}$ & $\begin{array}{r}0.007931 \\
(0.26)\end{array}$ & $\begin{array}{r}-0.004163 \\
(-0.73)\end{array}$ & $\begin{array}{r}-0.008925 \\
(-0.40)\end{array}$ \\
\hline $\begin{array}{l}\text { CGARCH } \\
\text { volatility }\end{array}$ & $\begin{array}{r}9.42 \mathrm{E}-08 \\
(0.06)\end{array}$ & $\begin{array}{r}-0.003543 \\
(-0.83)\end{array}$ & $\begin{array}{r}4.98 \mathrm{E}-05 \\
(2.71)^{*}\end{array}$ & $\begin{array}{r}-0.014439 \\
(-0.56)\end{array}$ & $\begin{array}{r}-0.00507 \\
(-1.05)\end{array}$ & $\begin{array}{r}-0.082781 \\
(-1.75)^{* *}\end{array}$ \\
\hline $\begin{array}{l}\text { Power GARCH } \\
\text { volatility }\end{array}$ & $\begin{array}{r}-2.29 \mathrm{E}-08 \\
(-0.41)\end{array}$ & $\begin{array}{r}0.017655 \\
(3.23)^{*}\end{array}$ & $\begin{array}{r}-4.67 \mathrm{E}-06 \\
(-0.81)\end{array}$ & $\begin{array}{r}0.001655 \\
(0.07)\end{array}$ & $\begin{array}{r}0.010276 \\
(1.71)^{* *}\end{array}$ & $\begin{array}{r}-0.010807 \\
(-0.33)\end{array}$ \\
\hline Shares price index & $\begin{array}{r}0.010454 \\
(4.70)^{*}\end{array}$ & $\begin{array}{r}0.054818 \\
(9.54)^{*}\end{array}$ & $\begin{array}{r}0.020111 \\
(1.97)^{*}\end{array}$ & $\begin{array}{r}0.010565 \\
(4.78)^{*}\end{array}$ & $\begin{array}{r}0.047867 \\
(8.75)^{*}\end{array}$ & $\begin{array}{r}0.021476 \\
(2.09)^{*}\end{array}$ \\
\hline Common constant & $\begin{array}{r}4.200393 \\
(9.84)^{*}\end{array}$ & $\begin{array}{r}0.443988 \\
(10.12)^{*}\end{array}$ & $\begin{array}{r}0.621099 \\
(9.61)^{*}\end{array}$ & $\begin{array}{r}4.243242 \\
(9.23)^{*}\end{array}$ & $\begin{array}{r}0.083307 \\
(2.05)^{*}\end{array}$ & $\begin{array}{r}0.618115 \\
(9.50)^{*}\end{array}$ \\
\hline $\begin{array}{l}1^{\text {st lagged real }} \\
\text { imports }\end{array}$ & $\begin{array}{l}0.954429 \\
(186.89)^{*}\end{array}$ & $\begin{array}{r}0.786846 \\
(79.01)^{*}\end{array}$ & $\begin{array}{r}-0.211206 \\
(-14.98)\end{array}$ & $\begin{array}{r}0.95451 \\
(187.01)^{*}\end{array}$ & $\begin{array}{r}0.822151 \\
(89.81)^{*}\end{array}$ & $\begin{array}{r}-0.210327 \\
(-14.89)^{*}\end{array}$ \\
\hline $\begin{array}{l}1^{\text {st }} \text { lag of inflation } \\
\text { rate }\end{array}$ & & & $\begin{array}{r}0.120238 \\
(2.52)^{*}\end{array}$ & & & $\begin{array}{r}0.101268 \\
(2.12)^{*}\end{array}$ \\
\hline $\begin{array}{l}2^{\text {nd }} \text { lag of inflation } \\
\text { rate }\end{array}$ & & $\begin{array}{r}-0.005952 \\
(-1.74)^{* *}\end{array}$ & & & & \\
\hline $\begin{array}{l}1^{\text {st }} \text { lag of real } \\
\text { foreign reserves }\end{array}$ & & $\begin{array}{r}0.005779 \\
(1.80)^{* *}\end{array}$ & & & & \\
\hline Adjusted $\mathrm{R}^{2}$ & 0.981326 & 0.984058 & 0.497562 & 0.981335 & 0.983773 & 0.495748 \\
\hline DW statistics & 2.650187 & 2.575752 & 2.299241 & 2.650121 & 2.629967 & 2.301654 \\
\hline
\end{tabular}

Note: Significant at $* 5 \%$ and $* * 10 \%$, respectively. 


\section{Table C1: List of countries selected for analysis}

\begin{tabular}{|c|c|c|c|}
\hline Sub-groups & $\begin{array}{c}\text { Countries ( } \sim \text { trade } \\
\text { share) a } \\
\end{array}$ & Currency & Abbreviations \\
\hline A) Developed countries & Australia & Dollar & ASD \\
\hline High-income OECD and & Belgium & Frank & BGF \\
\hline \multirow[t]{13}{*}{ NON-OECD $(15 / 66)$} & Canada $(1.3 \%)$ & Dollar & CAD \\
\hline & France $(2.5 \%)$ & Franc & FRF \\
\hline & Germany (4.9\%) & Deutschmark (Euro) & GDM \\
\hline & Hong Kong, China (3.1\%) & Dollar & HKD \\
\hline & Italy $(2.6 \%)$ & Lira (Euro) & ITL \\
\hline & Japan $(4.4 \%)$ & Yen & JPY \\
\hline & Korea $(2.5 \%)$ & Won & KRW \\
\hline & Kuwait & Dollar & KWD \\
\hline & Netherland (1.8\%) & Guilder & NLG \\
\hline & Singapore $(3.6 \%)$ & Dollar & SGD \\
\hline & Spain $(1.3 \%)$ & Peseta & SPP \\
\hline & UK $(5.2 \%)$ & Pound (sterling) & UKP \\
\hline & USA (14.4\%) & Dollar & USD \\
\hline B) Developing countries & Malaysia & Ringgit & MLR \\
\hline \multirow{4}{*}{$\begin{array}{l}\text { Middle-income countries } \\
(5 / 46)\end{array}$} & Mexico & Pound & MXP \\
\hline & Russia & Ruble & RUR \\
\hline & South Africa & Rand & SAR \\
\hline & Turkey & Lira & TRL \\
\hline \multirow{7}{*}{$\begin{array}{l}\text { Lower middle-income } \\
\text { countries }(7 / 55)\end{array}$} & China & Yuan & CHY \\
\hline & Egypt & Pound & EGP \\
\hline & India & Rupee & INR \\
\hline & Indonesia & Rupiah & ISR \\
\hline & Pakistan & Rupee & PKR \\
\hline & Sri Lanka & Rupee & SLR \\
\hline & Thailand & Baht & THB \\
\hline \multirow{2}{*}{$\begin{array}{l}\text { Low-income countries } \\
(2 / 43)\end{array}$} & Bangladesh & Taka & BDT \\
\hline & Kenya & Shilling & KNS \\
\hline
\end{tabular}

Notes: * Sample of countries selected on the basis of our prime focus on Asian and Middle Eastern developing countries. However, according to the classification of the World Bank in October 2009, each group is represented on the basis of "country groups by income." Major criteria for sample countries include the relatively significant trade magnitude, i.e., exports are either higher than or equal to at least $\$ 10$ million per month on average or imports are more than $\$ 20$ million per month on average or both with Pakistan.

$\sim$ Values in braces show the share of major trading partners of Pakistan. Total is $47.6 \%$ (for 12 major trade partners). These are included to analyze in the context of trade and capital flows. Some countries are excluded or partially analyzed due to short/nonavailability of relevant (frequency) data: Afghanistan, Iran, Oman, Qatar, Saudi Arabia and UAE. a See Table 1, p. 3, in Z. Aftab \& S. Khan. (2008). Bilateral J-curves between Pakistan and her trading partners (PIDE Working Paper No. 45). 
Figure C1: Volatility and trade time-series in short run for Pakistan -DLNVOLG_PKR DLNRXS_PKR DLNRMS_PKR

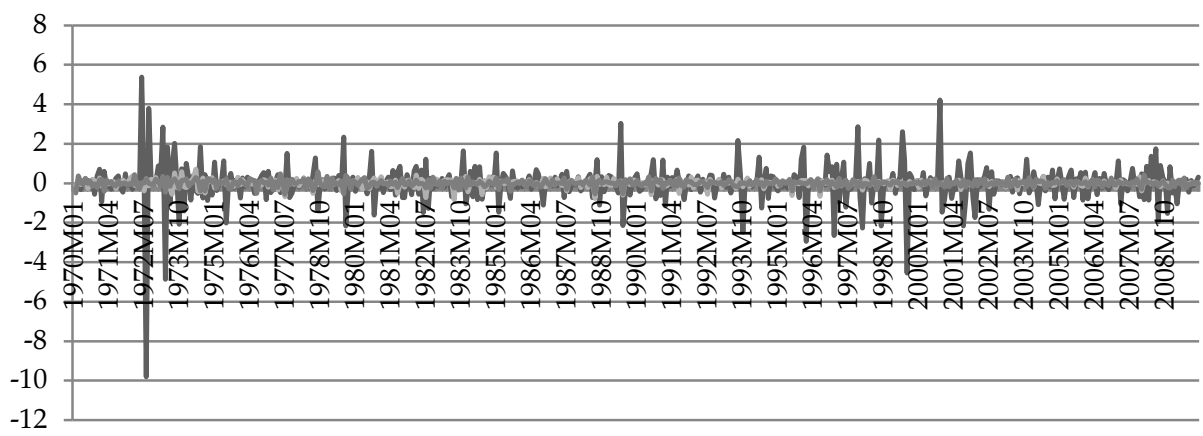

Figure C2: Volatility and trade time-series in long run for Pakistan

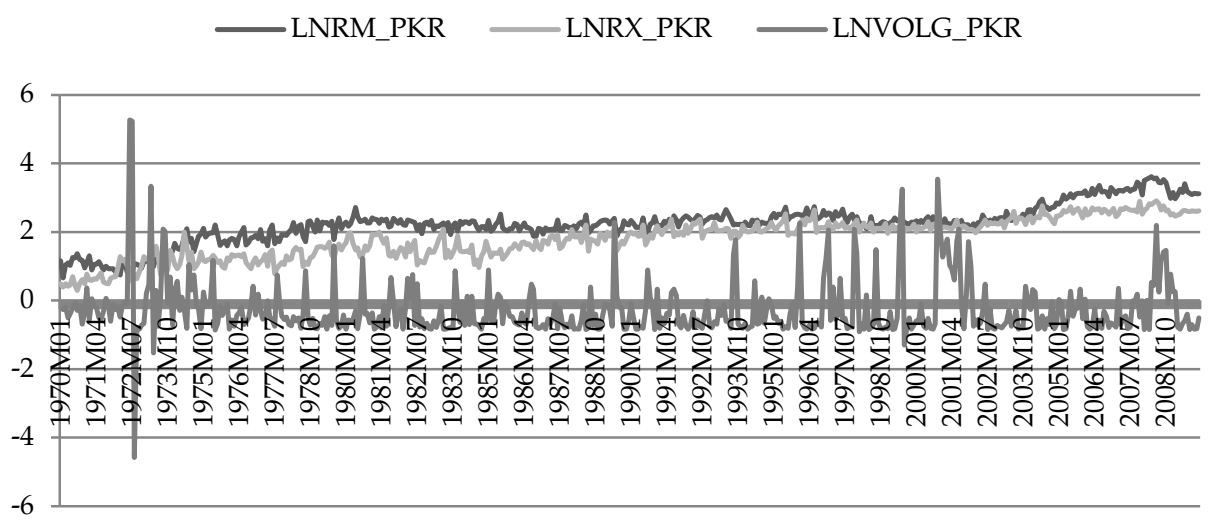

